\title{
Türk Yükseköğreniminin ISCED Geniş ve Dar Alan Sınıflaması
}

\author{
Metin Toprak ${ }^{1 *}$, Deniz Kolat ${ }^{2}$, Mehmet Şengül| ${ }^{3}$, Armağan Erdoğan ${ }^{4}$ \\ ${ }^{1}$ İstanbul Üniversitesi, ${ }^{2}$ Batman Üniversitesi, ${ }^{3}$ Mustafa Kemal Üniversitesi, ${ }^{4}$ Ankara Sosyal Bilimler Üniversitesi \\ ORCID: M. Toprak (0000-0001-9217-6318)
}

\begin{abstract}
Özet
Türk yükseköğrenim sistemindeki alan ve programlara yönelik standartlar, yeterlilikler, kalite güvencesi, akreditasyon ve önceki ögrenmelerin tanınması ve transferi konularında geliștirilecek düzenlemeler ile yönetișim ve işletim modeline zemin olușturmak üzere bu çalıșma gerçekleștirilmiştir. Bu çalışmada Türk yükseköğrenim sistemi, UNESCO’nun geliştirdiği eğitim sınıflaması (ISCED) çerçevesinde; 10 geniş alan ve 29 dar alandaki program çeşidi ve sayısı ile öğrenci ve öğretim elemanı mevcudu itibariyle sayısal olarak incelenmiștir. ISCED'deki 80 ayrıntılı alan ve eğitim programları düzeyindeki analizler, başka çalıșmalara bırakılmıștır. ISCED geniș alanlarında, program sayısı bakımından en fazla program işletme, yönetim ve hukuk (\%18,4); mühendislik, imalat ve inşaat $(\% 17,4)$; sağlık ve refah $(\% 14,9)$ ve sanat ve beșerî bilimler (\%14,2) geniş alanlarındadır. Öğrenci sayısının (açık öğretim hariç) en yüksek olduğu beş geniş alan işletme, yönetim ve hukuk (\%21,3), mühendislik, imalat ve inşaat $(\% 20,6)$, sanat ve beșerî bilimler $(\% 14,8)$, sağlık ve refah $(\% 12,6)$ ve eğitimdir $(\% 9,2)$. Öğretim elemanlarının en fazla olduğu beș geniş alan sağlık ve refah (\%37,7), mühendislik, imalat ve inşaat (\%15,4), eğitim (\%13,6), işletme, yönetim ve hukuk $(\% 9,9)$ ve doğa bilimleri, matematik ve istatistiktir $(\% 5,9)$. Öğretim elemanı başına düşen öğrenci sayısının en yüksek olduğu ilk beș geniș alan bilgi ve iletişim teknolojileri (50), işletme, yönetim ve hukuk (47), hizmetler (45), sosyal bilimler, gazetecilik ve enformasyon (35) ve eğitimdir (35). Program sayısı başına en fazla öğrenci sırasıyla sosyal bilimler, gazetecilik ve enformasyon (90), mühendislik, imalat ve inşaat (90), işletme, yönetim ve hukuk (87), eğitim (79) ve sanat ve beșeri bilimlerdir (78). Program sayısı ve öğrenci sayısının geniş ve dar alanlar itibariyle dağılımı birbirine paralellik gösterirken, öğretim elemanları bakımından bu paralellik gözlenmiyor. Program çeșidi ve sayısı ile programlar itibariyle öğretim elemanı ve öğrenci sayıları ile eğitim, meslek ve ekonomik faaliyet ilișkisi, ülkenin gelecek tasavvurunda kritik önemdedir. Bu çalışma, söz konusu bağlantının ilk adımı olarak değerlendirilmektedir.

Anahtar Kelimeler: ISCED geniș ve dar alan sınıflaması, Türkiye yükseköğretim yeterlilikler çerçevesi, Temel alan yeterlilikleri, Avrupa Yeterlilikler Çerçevesi, Türkiye Yeterlilikler Çerçevesi.
\end{abstract}

\section{Isced Broad and Narrow Fields Classification of Turkish Higher Education}

\begin{abstract}
This study was carried out to provide the basis for governance and operation model with the regulations to be developed in terms of standards, qualifications, quality assurance, accreditation and recognition and transfer of prior learning for the fields and programs in the Turkish higher education system. In this study, the Turkish higher education system has been analyzed within the framework of the education classification (ISCED) developed by UNESCO. The number and types of programs in 10 broad and 29 narrow fields and the number of students and faculty members were analyzed numerically. Analyses at the level of 80 detailed fields and educational programs at ISCED are left to other studies. In ISCED broad fields, the highest number of programs is in business, administration and, law (18,4\%); engineering, manufacturing and construction (17,4\%); health and well-being $(14,9 \%)$ and arts and humanities $(14,2 \%)$, respectively. The five broad fields with the highest number of students in formal education are business, management and law (21,3\%), engineering, manufacturing and construction (20,6\%), arts and humanities $(14,8 \%)$, health and welfare $(\%), 12,6)$ and education $(9,2 \%)$, respectively. The five broad fields with the highest number of faculty members are health and welfare $(37,7 \%)$, engineering, manufacturing and construction $(15,4 \%)$, education (13,6\%), business, management and law $(9,9 \%)$, and natural sciences, mathematics and statistics $(5,9 \%)$, respectively. In the highest number of students per instructor, the first five broad fields are information and communication technologies (50), business, management and law (47), services (45), social sciences, journalism and information (35) and education (35). The highest number of students among the broad fields is sorted as social sciences, journalism and information (90), engineering, manufacturing and construction (90), business, management and law (87), education (79), and arts and humanities (78). The distribution of the number of programs and the students shows a parallelism in the broad fields. However, same parallelism is not observed in the distribution of teaching staff by fields. The type and number of programs and the number of teaching staff and students by programs and the relationship between education, occupation and economic activity are critical in the country's future imagination. This study is considered as the first step of this connection.
\end{abstract}

Key Words: ISCED broad and narrow fields classification, Turkish higher education qualifications framework, Basic fields qualifications, European Qualifications Framework, Turkish Qualifications Framework.

*Yazışma Adresi / Address for Correspondence: Metin Toprak, Email: metin.toprak@istanbul.edu.tr

Geliş Tarihi / Received Date: 26.08.2019

Kabul Tarihi / Accepted Date: 16.12 .2019

Doi: $10.26701 /$ uad.611011

\section{Giriș}

Bugün, akademi ve iş dünyası platformlarında ülkelerin rekabetçilik düzeyi, ekonomik ve insani gelişmişlik düzeyleri ile mesleki ve yükseköğrenim sıklıkla birlikte kullanılmakta ve endüstri 4.0 kavramına paralel içerim- 
lerle üniversite 4.0 veya yeni nesil üniversite kavramları ortaya atılmaktadır. Bugünün Türkiye'si geçmişin eğitim kurumları kapasitesi ile şekillendi ve geleceğin Türkiye'si de bugünün kapasitesi ile şekillenecektir. Geleceğin teknolojileri, meslekleri ve ekonomik faaliyetleri ile bugünün yükseköğrenim programlarından mezun olanlar iştigal edecektir (Mongkolhutthi, 2019; Stonkiene, Matkeviciene ve Vaiginiene, 2016). Bu nedenle, ISCED siniflaması çerçevesinde program çeşidi, program sayısı ve öğrenci sayısı analiz edilerek betimsel düzeyde niceliksel bir değerlendirme yapılacaktır.

Son yirmi yılda giderek artan oranda mesleki ve akademik lisansüstü program ayırımı dikkat çekmektedir. Mesleki yüksek lisans programları yaygın olmakla birlikte, YÖK'te doktora programları akademik nitelikte tanımlandığı için ikinci öğretim veya uzaktan öğretim programı olarak açılmaları söz konusu olmamaktadır. Aynı şekilde, doktoraya eşdeğer olan sanatta yeterlik programları da birinci eğitim programı olarak açılabilmektedir. Doktora eğitimine denk olan tıpta uzmanlık, diş hekimliğinde uzmanlık, eczacılıkta uzmanlık, veterinerlikte uzmanlık programları ise ilgili bakanlıkların araştırma ve uygulama birimlerinde "mesleki doktora" olarak nitelenebilecek formatta yürütülmektedir. Dolayısıyla, açıkça ifade edilmese de yükseköğretim kurumlarında yürütülen doktora programları "akademik doktora", Sağlık Bakanlığı ve Tarım Bakanlığı gibi araştırma ve uygulama kapasitesine sahip idari birimlerde yürütülen ihtisas programları "mesleki doktora" olarak kabul edilmektedir (Yağan ve Çubukçu, 2019; Toprak ve Erdoğan, 2013).

\section{GENIŞ ALANLAR ITIBARIYLE YÜKSEKÖĞRENIM PROGRAMLARI, ÖĞRENCILER VE ÖĞRETIM ELEMANLARI}

ISCED, Birleşmiş Milletler Eğitim, Bilim ve Kültür Örgütü (UNESCO) tarafından geliştirilen bir sınıflama olup, uluslararası düzeyde karşılaştırma yapmada ve ulusal düzeyde ise planlama ve değerlendirmelerde kullanılan bir araçtır (Toprak, Kolat ve Şengül, 2018). ISCED çerçevesinde yükseköğrenim programları geniş, dar ve ayrıntılı olmak üzere üç farklı kırılımda sınıflandırılmaktadır. Geniş alan sayısı 11 ve dar alan sayısı 29 iken, ayrıntılı alan sayısı ise 80 civarındadır.

\subsection{Program çeşidi ve program sayısının geniş alanlar arasındaki dağılımı}

ISCED sınıflaması içindeki 10 geniş alandaki toplam program çeşidi en çok olan üç alan sırasıyla sanat ve beșerî bilimler $(\% 17,7)$, mühendislik, imalat ve inşaat $(\% 16,7)$, işletme, yönetim ve hukuk $(\% 16,3)$ geniş alanlarıdır. Program çeşidi en az olan alanlar ise sırasıyla bilgi ve iletişim teknolojileri $(\% 1,9)$, hizmetler $(\% 4,5)$ ve ziraat, ormancılık, balıkçılık ve veterinerlik $(\% 4,6)$, geniş alanlarıdır (Şekil 2.1).

ISCED geniş alanlarının program çeşitliliği bakımından farklılaşmasında en etkili faktör, uzun bir tarihi geçmişi bulunan programların çeşit olarak kendilerini sürdürmeleridir. Dolayısıyla, işgücü piyasasında yüksek bir karşılığının olması veya akademik veya mesleki nitelikte olması ana faktörler değildir.

ISCED sınıflaması içindeki 10 geniş alandaki toplam program sayısının dağılımında ilk üç alan sırasıyla işletme, yönetim ve hukuk $(\% 18,4)$, mühendislik, imalat ve inşaat $(\% 17,4)$ ve sağlık ve refah $(\% 14,9)$ geniş alanlarıdır. Program sayısı en az olan alanlar ise sırasıyla bilgi ve iletişim teknolojileri $(\% 1,6)$, ziraat, ormancılık, balıkçılık ve veterinerlik $(\% 3,6)$ ve hizmetler $(\% 5,9)$ geniş alanlarıdır (Şekil 2.2).

Program sayısının geniş alanlar itibariyle dağılımında, işgücü piyasasının ve ekonomik sektörlerin ihtiyaçlarının nispeten daha fazla etkili olduğu söylenebilir. Nitekim program çeşidi en yüksek oranda olan sanat ve beşerî bilimler geniş alanı, program sayısı bakımından dördüncü siraya gerilemektedir.

\subsection{Geniş alan bazında, program çeşidi başına düşen program sayısı}

Program çeşitliliği bakımından en fazla sayıda programı bulunan üç geniş alan sırasıyla hizmetler, eğitim ve sağlık ve refah geniş alanlarıdır. Hizmetlerde program çeşidi başına düşen program sayısı ortalama 10,7 iken, bu oran eğitimde 10 ve sağlık ve refahta 9,6'dır. Program çeşidi başına en az sayıda programı bulunan üç geniş alan sırasıyla ziraat, ormancılık, balıkçılık ve veterinerlik $(6,4)$, sanat ve beşeri bilimler $(6,5)$ ve doğa bilimleri, matematik ve istatistik $(6,6)$ geniş alanlarıdır (Şekil 2.3).

Disiplinler arası veya hibrit programlara sahip geniş alanlarda program sayısı fazla, uygulamadan ziyade teorik yanı ağır basan ve doğrudan istihdam ve piyasayı hedeflemeyen daha ziyade temel doğa bilimi veya temel sosyal bilim niteliğinde olan bilim alanlarında ise program sayısı sinırlidir.

\subsection{Geniş alan bazında, program sayısı başına düşen öğrenci sayısı}

Program sayısı başına en çok öğrenci düşen üç geniş alan sırasıyla sosyal bilimler, gazetecilik ve enformasyon (90), mühendislik, imalat ve inşaat $(89,5)$ ve işletme, yönetim ve hukuk $(87,1)$ geniş alanlarıdır. Program sayısı başına en az öğrenci düşen üç geniş alan sırasıyla doğa bilimleri, matematik ve istatistik $(41,3)$, ziraat, ormancılık, balıkçılık ve veterinerlik $(52,9)$ ve hizmetler $(58)$ geniş alanlarıdır (Şekil 2.4).

Öğrenciler, ekonomik sektörlerin ihtiyaçlarını önceleyen ve uygulamalı eğitim niteliği öne çıkan programları, görece yüksek istihdam şansı nedeniyle daha çok tercih ederken; istihdam alanları ekonomik sektörlerin gelişme örüntüsüne uymayan ve doğrudan istihdam alanlarını hedeflemeyen programlara ise daha düşük düzeyde yönelmektedirler. 


\section{4 Öğrenci sayısının geniş alanlar itibariyle dağılımı}

ISCED sınıflaması içindeki 10 geniş alanda öğrenci sayısı en çok olan üç alan sırasıyla işletme, yönetim ve hukuk $(\% 21,3)$, mühendislik, imalat ve inşaat $(\% 20,6)$, ve sanat ve beşeri bilimler $(\% 14,8)$ geniş alanlarıdır. Öğrenci sayısı en az olan alanlar ise sırasıyla bilgi ve iletişim teknolojileri $(\% 1,5)$, ziraat, ormancılık, balıkçılık ve veterinerlik $(\% 2,6)$ ve doğa bilimleri, matematik ve istatistik $(\% 4,4)$ geniş alanlarıdır (Şekil 2.5).

Öğrenci sayısının geniş alanlara dağılımında, işgücü piyasasındaki talebin etkili olduğu söylenebilir. Nitekim tarımdaki nispi gerilik, bu alandaki programlara yönelik talebin de düşük olmasına yol açmaktadır. Bilişim alanındaki programlara kayıtlı öğrenci sayısının düşüklüğü dikkate alındığında, dijitalleşen ekonominin ihtiyaç duyduğu BİT alanındaki yoğun insan gücü bakımından, Türk yükseköğreniminin yeterli dinamizmi göstermediği söylenebilir.

\subsection{Eğitim düzeyi bazında öğrencilerin geniş alanlar itibariyle dağılımı}

Farklı eğitim düzeylerinde en fazla öğrencinin bulunduğu alanlar ön lisansta işletme, yönetim ve hukuk, mühendislik, imalat ve inşaat ve sağlık ve refahtır. Lisans düzeyinde en fazla öğrencinin bulunduğu alanlar mühendislik, imalat ve inşaat, sanat ve beşerî bilimler ile işletme, yönetim ve hukuktur. Yüksek lisans düzeyinde işletme, yönetim ve hukuk, mühendislik, imalat ve inşaat ve sanat ve beşerî bilimler en fazla öğrencinin öğrenim gördüğ ü alanlardır. Sanatta yeterlikte öğrencilerin \%99,1'i sanat ve beşerî bilimler alanında kayıtlı iken, mühendislik, imalat ve inşaat alanında kayıt öğrencilerin oranı \%0,9'dur. Doktora eğitiminde en fazla öğrenci mühendislik, imalat ve inşaat, işletme, yönetim ve hukuk ve sanat ve beșerî bilimler alanlarında kayıtlıdır (Tablo 2.1).

Türk yükseköğreniminde, istihdam alanları en geniş olabilecek işletme ve mühendislik gibi uygulamaya yönelik programlar, öğrenciler tarafından daha fazla rağbet görmektedir. Endüstri 4.0 dalgasının ekonomilere etkileri düşünüldüğünde, BİT alanında ve matematik ve istatistik alanında kayıtlı ögrencilerin görece düşük düzeyde olduğu, dijitalleşen bir ekonomi, yönetim ve eğitimi hedefle-

Tablo 2.1. ISCED geniş alanları itibariyle farklı eğitim

\begin{tabular}{|c|c|c|c|c|c|c|c|}
\hline Geniş alan & Ön lisans & Lisans & $\begin{array}{l}\text { Yüksek } \\
\text { Lisans }\end{array}$ & Sanatta Yeterlik & Doktora & Toplam & Toplam (adet) \\
\hline 01 Eğitim & 3,9 & 11,5 & 8,6 & 0,0 & 7,1 & 9,2 & 311.349 \\
\hline 02 Sanat ve beşeri bilimler & 6,1 & 18,3 & 14,5 & 99,1 & 15,8 & 14,8 & 502.012 \\
\hline 03 Sosyal bilimler, gazetecilik ve enformasyon & 0,3 & 11,4 & 11,0 & 0,0 & 10,4 & 8,5 & 290.123 \\
\hline 04 İşletme, yönetim ve hukuk & 32,5 & 15,9 & 26,6 & 0,0 & 16,4 & 21,3 & 724.917 \\
\hline 05 Doğa bilimleri, matematik ve istatistik & 0,2 & 4,9 & 8,1 & 0,0 & 13,6 & 4,4 & 148.134 \\
\hline 06 Bilgi ve İletişim Teknolojileri & 4,9 & 0,4 & 0,7 & 0,0 & 0,4 & 1,5 & 52.540 \\
\hline 07 Mühendislik, imalat ve inşaat & 19,6 & 21,5 & 18,3 & 0,9 & 21,5 & 20,6 & 702.374 \\
\hline 08 Ziraat, ormancılık, balıkçılık ve veterinerlik & 3,0 & 2,1 & 3,7 & 0,0 & 4,2 & 2,6 & 87.068 \\
\hline 09 Sağlık ve refah & 18,6 & 11,7 & 4,7 & 0,0 & 9,2 & 12,6 & 427.778 \\
\hline 10 Hizmetler & 10,9 & 2,2 & 3,9 & 0,0 & 1,4 & 4,6 & 155.694 \\
\hline Toplam & 100,0 & 100,0 & 100,0 & 100,0 & 100,0 & 100,0 & 3.401 .989 \\
\hline
\end{tabular}

Kaynak: YÖKSiS veri tabanı, Mart 2019.

yen bir ülke için bu durumun kaygı verici olduğu söylenebilir Ekonomik sektörlerin değişen teknoloji ve iş yapma tarzlarına uyumları ile üniversiteler arasında bir kopukluğun olduğu, üniversite müfredatlarının bu nedenle dijitalleşme yönünde yeterli uyumu göstermediği söylenebilir (Nguyen ve Laws, 2019; Tay ve Low, 2017).

\subsection{Geniş alan bazında öğrenci sayısının farklı eğitim düzeylerine göre dağılımı}

Toplam öğrenci sayısı içinde ön lisans programlarına kayıtlı öğrenci oranı en yüksek geniş alanlar bilgi ve iletişim teknolojileri (\%80), hizmetler (\%60), işletme, yönetim ve hukuk (\%39) ve sağlık ve refah (\%37) programları iken; ön lisanstaki öğrenci oranı en düşük olan geniş alanlar ise sosyal bilimler, gazetecilik ve enformasyon $(\% 0,9)$, doğa bilimleri, matematik ve istatistik $(\% 1,4)$ ve sanat ve beşeri bilimlerdir $(\% 10,4)$ (Tablo 2.2).

İşgücü piyasasında yüksek karşılığı olan ve daha ziyade ara eleman yetiştirmek üzere eğitim veren programların bulunduğu geniş alanlarda ön lisanstaki öğrenci oranı da yüksektir. Bilgi ve iletişim, hizmetler, işletme, yönetim ve hukuk ile sağlık ve refah alanlarındaki programlarda ön lisans öğrenci oranı oldukça yüksektir. Dolayısıyla, ekonomik sektörlerin ara eleman ve destek elemanı ihtiyacının olduğu işgücü piyasasının özelliklerine paralel bir durum söz konusudur. Nitekim işgücü piyasasında karşılığı düşük olan alanlarda, ön lisans düzeyindeki öğrenci oranı oldukça düşüktür.

Lisans programlarına kayıtlı öğrenci sayısının toplam öğrenci sayısı içindeki oranı en yüksek geniş alanlar sosyal bilimler, gazetecilik ve enformasyon (\%81), eğitim (\%76) ve sanat ve beşerî bilimler (\%75) programları iken; lisansta kayıtlı öğrenci oranı en düşük olan geniş alanlar ise bilgi ve iletişim teknolojileri (\%14), hizmetler (\%29) ve işletme, yönetim ve hukuktur (\%45) (Tablo 2.2).

Lisans eğitiminde kayıtlı öğrencilerin toplam öğrenciler içindeki oranı en yüksek geniş alanlar; sosyal bilimler, gazetecilik ve enformasyon, eğitim ve sanat ve beşerî bilimler gibi nispeten akademik niteliği öne çıkan alanlardır. Lisansta kayıtlı öğrencilerin en düşük oranda olduğu alanlar ise ara eleman yetiştirme niteliği yüksek olan bilgi ve iletişim teknolojileri, hizmetler ve işletme, yönetim ve üzeylerindeki öğrenci sayıları (\%, açık öğretim hariç) 
hukuk geniş alanlarıdır.

Yüksek lisanstaki öğrenci oranı en yüksek geniş alanlar doğa bilimleri, matematik ve istatistik (\%21), ziraat, ormancılık, balıç̧ılık ve veterinerlik (\%16) ve sosyal bilimler, gazetecilik ve enformasyon (\%15) programlarıdır. Yüksek lisansta kayıtlı öğrenci sayısının toplam öğrenci sayısı içindeki oranının en düşük olduğu geniş alanlar ise sağlık ve refah (\%4), bilgi ve iletişim teknolojileri (\%5) ve hizmetler (\%10) programlarıdır (Tablo 2.2).

Yüksek lisans eğitimi, niteliği gereği disiplinler arası eğitime veya farklı alana yönelerek lisanstaki alanı değiştirme ve çeşitlendirme amacı için oldukça uygun bir eğitim düzeyidir. Örneğin, tezsiz yüksek lisans programları akademik olmaktan ziyade mesleki eğilimi yüksek olup, kişilere farklı alanlarda beceri ağırlıklı eğitim vermeyi amaçlar. Ancak, Türk yükseköğrenim sisteminde bu özelliğin yaygınlık kazanmadığı söylenebilir. Yüksek lisansa kayıtlı öğrenci sayısı, toplam öğrenci sayısı içinde en yüksek orana sahip geniş alanlar, beklentinin aksine akademik nitelikli olup, doğa bilimleri, matematik ve istatistik, ziraat, ormancılık, balıkçılık ve veterinerlik ve sosyal bilimler, gazetecilik ve enformasyon olarak siralanmaktadır.

Sanatta yeterlik programlarının hemen hemen tamamı sanat ve beşerî bilimlerde bulunmakta, ancak kayıtlı öğrenci sayısı, bu geniş alandaki toplam öğrenci sayısı içinde \%0,2'lik düşük bir paya sahiptir. Doktora programındaki öğrenci sayısının en yüksek olduğu geniş alanlar doğa bilimleri, matematik ve istatistik (\%8), ziraat, ormancılı, balıkçılık ve veterinerlik (\%4) ve sosyal bilimler, gazetecilik ve enformasyon (\%3) programlarıdır. Doktoraya kayıtlı öğrenci sayısının toplam öğrenci sayısı içindeki payı en düşük olan alanlar ise bilgi ve iletişim teknolojileri $(\% 0,7)$, hizmetler $(\% 0,8)$ ve sağlık ve refah $(\% 2)$ programlarıdır (Tablo 2.2).

Doktora eğitiminde kayıtlı öğrenci sayısı, toplam öğrenci sayısı içinde en yüksek olan programlar doğal olarak akademik yönelimi ağır basan geniş alanlara aittir. Temel doğa, sosyal ve beşeri bilimlerden mezun olanlara yönelik işgücü piyasasındaki talep, diğer uygulamalı alanlardan mezun olanlara göre nispeten daha düşüktür. $\mathrm{Bu}$ temel alanlardan mezun olanların akademik lisansüstü eğitime yönelmelerinde, işgücü piyasasındaki sıkışıklığın da etkili olduğu söylenebilir. Dolayısıyla, doktora yapmak için tezli yüksek lisans yapma şartı olduğu için, işgücü piyasasında taleple aynı doğrultuda olmasa da temel doğa, beşerî ve sosyal bilim alanlarında daha fazla yüksek lisans ve doktora yapma gibi bir durum ortaya çıkmaktadır.

\section{7 Öğretim elemanı sayısının geniş alanlar itibariyle dağılımı}

Öğretim elemanı sayısı, izlenen metodoloji bakımından farklılaşmaktadır. Örneğin, Kıbrıs Türk kesimindeki öğretim elemanları veya yabancı uyruklu öğretim elemanlarının dikkate alınmasına göre toplam sayı farklılaşmaktadır. Bu çalışmada 2019 Mart sonu itibariyle YÖKSİS veri tabanındaki durum dikkate alınmış ve Kıbrıs Türk Kesimindeki sayısı 2.000 civarında olan öğretim elemanları dikkate alınmamıştır.

ISCED'in 10 geniş alanında öğretim elemanı sayısı en çok olan üç alan sırasıyla sağlık ve refah $(\% 37,7)$, mühendislik, imalat ve inşaat $(\% 15,4)$, ve sanat ve beşerî bilimler $(\% 13,6)$ geniş alanlarıdır. Öğretim elemanı sayısı en az olan alanlar ise sırasıyla bilgi ve iletişim teknolojileri $(\% 0,7)$, hizmetler $(\% 2,2)$ ve ziraat, ormancılık, balıkçılık ve veterinerlik (\%3,7) geniş alanlarıdır (Şekil 2.6).

Dünyada ve Türkiye'de yükselen ekonomik sektörler, daha ziyade 21'inci yüzyıl becerilerini gerektiren ve bilişim ve teknoloji yönelimli sektörlerdir. Bilişimdeki çok hızlı değişim ve dönüşümler, yükseköğrenim kurumlarının öğretim elemanı ihtiyacını aynı hızda temin etmesini neredeyse imkânsız kılmaktadır. Türkiye'de yabancı uyruklu öğretim elemanı çalıştırılmasına yönelik olumsuz yaklaşım, sadece kısa vadede değil ama uzun vadede de Türk yükseköğrenimi için ciddi bir handikaptır. Yükseköğretim Kurumları Öğretim Elemanlarının Kadroları Hakkında Kanun Hükmünde Kararnamenin Ek 14'üncü maddesine göre yabancı uyruklu öğretim elemanı sayısı dolu öğretim elemanı kadrosu sayısının \%2'sini geçemez. Ayrıca, yabancı uyruklu öğretim elemanları, YÖK'ün programlar için öngördüğü asgari öğretim elemanı sayısı içinde kabul edilmemektedir. Her ne kadar YÖK uygulamada \%2 ora-

Tablo 2.2. ISCED geniş alanları itibariyle farklı eğitim düzeylerindeki öğrenci sayıları (\%, açık öğretim hariç)

\begin{tabular}{|c|c|c|c|c|c|c|c|}
\hline Geniş alan & Toplam sayı & Ön lisans & Lisans & $\begin{array}{l}\text { Yüksek } \\
\text { Lisans }\end{array}$ & $\begin{array}{l}\text { Sanatta } \\
\text { Yeterlik }\end{array}$ & Doktora & Toplam \\
\hline 01 Eğitim & 311.349 & 10,8 & 76,4 & 10,7 & 0,0 & 2,1 & 100,0 \\
\hline 02 Sanat ve beşerî bilimler & 502.012 & 10,4 & 75,3 & 11,2 & 0,2 & 2,9 & 100,0 \\
\hline 03 Sosyal bilimler, gazetecilik ve enformasyon & 290.123 & 0,9 & 81,2 & 14,7 & 0,0 & 3,3 & 100,0 \\
\hline 04 İşletme, yönetim ve hukuk & 724.917 & 38,5 & 45,2 & 14,2 & 0,0 & 2,1 & 100,0 \\
\hline 05 Doğa bilimleri, matematik ve istatistik & 148.134 & 1,4 & 68,9 & 21,3 & 0,0 & 8,4 & 100,0 \\
\hline 06 Bilgi ve İletişim Teknolojileri & 52.540 & 80,0 & 14,4 & 4,8 & 0,0 & 0,7 & 100,0 \\
\hline 07 Mühendislik, imalat ve inşaat & 702.374 & 24,0 & 63,1 & 10,1 & 0,0 & 2,8 & 100,0 \\
\hline 08 Ziraat, ormancılık, balıkçılık ve veterinerlik & 87.068 & 29,4 & 49,8 & 16,4 & 0,0 & 4,4 & 100,0 \\
\hline 09 Sağlık ve refah & 427.778 & 37,4 & 56,4 & 4,2 & 0,0 & 2,0 & 100,0 \\
\hline 10 Hizmetler & 155.694 & 60,1 & 29,3 & 9,8 & 0,0 & 0,8 & 100,0 \\
\hline Toplam (Adet) & 3.401 .989 & 858.350 & 2.062 .674 & 388.232 & 1.223 & 91.510 & 100,0 \\
\hline Toplam (\%) & 100,0 & 25,2 & 60,6 & 11,4 & 0,04 & 2,7 & \\
\hline
\end{tabular}

Kaynak: YÖKSiS veri tabanı, Mart 2019 
nını kurum bazında dikkate almasa da, uluslararasılașan bir yükseköğrenimde, söz konusu önemli bir engeldir.

Öğretim elemanı yetiştirmek üzere, öğrencilerin yurtdışına gönderilmeleri, Türkiye'de İngilizce eğitim yapan köklü ve prestijli üniversitelere yönlendirilmeleri, yabancı uyruklu yetkin akademisyenlerin, lisansüstü eğitimde danışmanlık ve yönlendirme yapmak üzere Türkiye'deki üniversitelerde görevlendirilmeleri, Türk üniversitelerinin konsorsiyum kurarak lisansüstü eğitimi ortak sürdürmeleri, yurtiçi ve yurtdışı bütünleşik ve ortaklaşa lisansüstü program yürütülmesi ve nihayet Türk üniversitelerinin yurtdışında yerleşke açarak ortak veya bireysel olarak eğitim ve araştırma faaliyetinde bulunmaları gibi farklı seçenekler yoğun olarak tartışılmaktadır. Ancak, Türkiye'nin resmi adayı olduğu Avrupa Birliği coğrafyası ile tarihi ve kültürel yakın ilişkileri bulunan eski Osmanlı coğrafyalarındaki araştırma ve eğitim imkânlarını yeterince değerlendirdiği söylenemez. Yürütülen iddialı projelerin bir kısmı amaç ve hedefler bakımından (Mevlana Projesi ve Türkiye Bursları gibi), bir kısmı finansman bakımından (Farabi Projesi gibi), bir kısmı da tasarım bakımından (MEB yoluyla gönderilenler) ciddi handikaplara maruzdur. Türk dış politikasındaki coğrafi ve politik açılımlar dikkate alındığında, eğitimdeki açılımın bu doğrultuda yürütülmeye çalışıldığı anlaşılabilir. Dolayısıyla eğitim ve ekonominin yüksek etkileşim içindeki iki alan olduğu göz önüne alındığında, Osmanlı milletler topluluğu ile Avrupa'nın Türkiye bakımından işbirliğinin geliştirileceği öncelikli hedef coğrafyalar ve toplumlar olduğu söylenebilir.

Öğretim elemanlarının geniş alanlara dağılımında işgücü piyasası ve ekonomik sektörler önemli bir faktör olarak görünmektedir. Uygulamalı eğitim niteliğinden dolayı sağlık programlarında görev yapan öğretim elemanlarının sayısı çarpıcı bir farklılık göstermektedir. Ancak bilişim ve teknoloji alanında kadrolu öğretim elemanlarının sayısı ise dijitalleşen ekonomide göreli olarak yetersiz düzeydedir.

Öğretim elemanı başına düşen öğrenci sayısı en yüksek üç geniş alan sırasıyla bilgi ve iletişim teknolojileri (50), işletme, yönetim ve hukuk (47) ve hizmetlerdir (45). Söz konusu oranın en düşük olduğu geniş alanlar ise sırasıyla sağlık ve refah (7), ziraat, ormancılık, balıkçılık ve veterinerlik (1\%) ve doğa bilimleri, matematik ve istatistiktir (16).

Alanlar itibariyle öğretim elemanı başına düşen öğrenci sayısında iki farklı özellik söz konusudur. İlk olarak, sağlık programları daha ziyade uygulamalı eğitim modeline dayandığı için uygulama, laboratuvar ve stajın ortaya çıkardığı yük nedeniyle, hoca başına daha az öğrenci düşmektedir. İkinci olarak, istihdam alanındaki yetersizlik nedeniyle öğrencinin düşük düzeyde talepte bulunduğu alanlar söz konusudur.

Türk yükseköğrenimi genelinde öğretim elemanı başına düşen ortalama öğrenci sayısının 22 civarında olduğu dikkate alındığında, sırasıyla bilgi ve iletişim teknolojileri; işletme, yönetim ve hukuk; hizmetler; sosyal bilimler, gazetecilik ve enformasyon; eğitim; mühendislik, imalat ve inşaat ve sanat ve beşeri bilimler programlarında ortalamanın üstünde öğretim elemanı başına öğrenci düştüğü görülmektedir. Öğretim elemanı başına düşen öğrenci sayısı ortalamanın altında olan geniş alan programları ise sırasıyla sağlık ve refah; ziraat, ormancılık, balıkçılık ve veterinerlik ile doğa bilimleri, matematik ve istatistik programlarıdır (Şekil 2.7).

Aşağıda ISCED dar alanları program sayısı, öğrenci sayısı, program sayısı başına düşen öğrenci sayısı, öğretim elemanı sayısı ve öğretim elemanı sayısı başına düşen öğrenci sayısı bağlamında ele alınacaktır. Her bir dar alan, ait olduğu geniş alana ait değer referans alınarak yorumlanacaktır. İkinci bölümde geniş alanlar aynı değişkenler bakımından karşılaştırılmıştır. Bu bölümde ise her bir geniş alan kapsadığı dar alanlar itibariyle analiz edilmektedir. Böylece, bir geniş alanın kapsadığı dar alanlar bakımından yukarıdaki değişkenler çerçevesinde ne düzeyde farklılaştığı görülecektir.

\section{DAR ALANLAR ITIBARIYLE YÜKSEKÖĞRENIM PROGRAMLARI, ÖĞRENCILERI VE ÖĞRETIM ELEMANLARI}

ISCED sınıflamasında 10 geniş alan altında 29 dar alan bulunmakla birlikte, Türk yükseköğrenim sisteminde ISCED'de ilk geniş alan olan "genel programlar" altında herhangi bir program veya yeterlilik kodlanmamıştır. Her bir dar alanda disiplinler arası programlar söz konusu olabilmektedir. Türk yükseköğrenim sisteminde, Hizmetler geniş alanında disiplinler arası program kodlanmamıştır. Sonuç olarak, Türk yükseköğrenim sistemindeki dar alan sayısı, ISCED çerçeve dokümanındaki sayıya yakındır (Tablo 5.1 ve 5.2 ).

Yükseköğrenim veri tabanındaki programlara ISCED sinıflamasına göre tek bir kod verilmesi, ancak uluslararası karşılaştırma ve raporlamalar bakımından genel bir fonksiyon görmekte; ancak ulusal ve bölgesel veya sektör ve işkolu bakımından sınırlı sonuçlar üretmektedir. Bu nedenle, disiplinler arası programların hızla arttığı dikkate alındığında, bir programın iki, üç hatta dört kodla tanımlanması oldukça işlevsel olabilir. Dolayısıyla, ilk kod doğrudan kod, ikinci, üçüncü ve hatta dördüncü kod dolaylı kodlar olarak tanımlanabilir. Müfredat geliştirmede iş dünyasının ihtiyaçlarını etkili bir şekilde dikkate alma ve transfer edilebilir beceriler kazandırma bakımından çoklu kod uygulaması oldukça yararlı olacaktır. Nitekim ISCED metninde, çoklu kod uygulamasının uluslararası karşılaştırmalarda ve raporlamalarda zorunlu olmadığı için ve ayrıca karmaşıklığı artıracağı için tercih edilmediği, ancak ulusal düzeyde kullanılmasının mümkün olduğuna işaret edilmektedir (Toprak, Kolat ve Şengül, 2018; Schneider, 2013). 


\subsection{Eğitim dar alanları}

Eğitim dar alanındaki programların neredeyse tamamı "eğitim dar alanı" altında sınıflandırılmıştır. Eğitim dar alanındaki disiplinler arası programlar ve yeterliliklerin sayısı, program çeşidi olarak 3, program sayısı olarak 4 ve öğrenci sayısı olarak 33 olduğu için, toplam içindeki oran sıfır olarak kabul edilebilir.

Eğitim dar alanında, program sayısı başına düşen öğrenci sayısı 79'dur. Eğitim geniş alanında ağırlıklı tek bir dar alan olduğu için, eğitim dar alanları itibariyle bir farklılaşma söz konusu değildir. Öğretim elemanı başına düşen öğrenci sayısı 35 civarında olup, yükseköğrenimdeki 22 olan genel ortalamadan $\% 59$ daha yüksektir (Tablo 5.2).

Eğitim alanındaki programlar, ülke gündemini oluşturacak derecede tartışma konusu olmaktadır. Alan uzmanlığı olan branşların eğitim fakültelerinden alınarak alan uzmanlığı olan fakültelere verilmesi, pedagojik formasyonu almanın bir ayrıcalık olarak görülmesi ve eğitim fakültesi mezunlarının dışında kalanlara ancak politik baskılarla veriliyor olması, bu alandaki otoritelerin ve sağlayıcıların güncel bağlamın uzağında kaldıklarına işaret etmektedir. Yetkinlik ve beceri odaklı uygulamalı eğitim, 21'inci yüzyıl becerileri, araştırma ve eğitim altyapıları, işbaşında ve işyerinde öğrenme yaklaşımı gibi yeni teknolojilerin gerektirdiği anlayış, politika ve araçları geliştirme anlayışı, henüz yeterince kabul görmüş değildir.

"Atanamayan öğretmen" kavramı, Türk eğitim sisteminin literatüre bir armağanıdır. İstikrarsız özel sektör ve yetersiz ekonomik büyüme, gençleri devlet kapısında iş aramaya yöneltmekte, geçmişten bu yana büyüklerinin tavsiyeleri de bu yönde olmaktadır. Ekonomik sektörlerdeki gelişmenin eğitimli nüfustaki artışla uyumlu olmaması, eğitim fakültelerine yönelik toplumsal algının yanlış oluşturulması ve nihayet beceri ve yetkinlik odaklı olmayan eğitim tasarımı ve müfredatından dolayı eğitim alanındaki programların ele alınmasında, yetkili kurumlar arasında ciddi bir karmaşa söz konusudur.

\subsection{Sanat ve beşerî bilimler dar alanları}

Sanat ve beşerî bilimler geniş alanında üç dar alan ve disiplinler arası programların bulunduğu bir karma alan bulunmaktadır: sanat, beșerî bilimler ve diller. Sanat ve beşerî bilimler geniş alanındaki programların \%49'u sanat, \%26'sı beşerî bilimler ve \%22'si diller dar alanları altındadır. Bu geniş alandaki disiplinler arası programların oranı ise \%3 civarındadır (Şekil 3.2.1).

Öğrencilerin dar alanlar itibariyle dağılımı program sayısındaki dağılımla paralellik göstermemektedir. Buna göre, öğrencilerin \%40'i beşerî bilimler dar alanındaki programlarda, \%31,6'sı sanat dar alanındaki programlarda, \%26,8'i diller dar alanındaki programlarda ve \%1,7'si disiplinler arası programlarda kayıtlıdır (Şekil 3.2.2).

Program başına düşen öğrenci sayısı sanat ve beşerî bilimler geniş alanında 78,3 olup, dar alanlar itibariyle fark- lılaşma göstermektedir. Buna göre, program sayısı başına düşen öğrenci sayısının yüksekten düşüğe doğru sanat, diller, beşerî bilimler ve disiplinler arası programlar olarak sıralanmaktadır (Şekil 3.2.3).

Öğretim elemanlarının dar alanlar itibariyle dağılımı, öğrencilerin dağılımına paralellik göstermektedir. Buna göre, öğretim elemanlarının \%44,5'i beşerî bilimler dar alanındaki programlarda, \%36,5'i sanat dar alanındaki programlarda, \%17,9'u diller dar alanındaki programlarda ve \%1,1'i disiplinler arası programlarda kadroludur (Şekil 3.2.4).

Sanat ve beşerî bilimler geniş alanında öğretim elemanı başına düşen öğrenci sayısı 24 civarındadır. Dar alanlar itibariyle bir farklılaşma gözlenmektedir. Öğretim elemanı başına düşen öğrenci sayısı ortalama olarak sanat dar alanında 17, beşerî bilimler dar alanında 26, diller dar alanında 35 ve disiplinler arası programlarda 37 civarındadır. Sanat ve beşerî bilimler geniş alanındaki dar alanlarda, öğretim elemanı başına düşen öğrenci sayısı, yükseköğrenimdeki 22 olan genel ortalamadan \%9 daha yüksektir. Sanat dar alanında, öğretim elemanı başına düşen öğrenci oranı Türkiye ortalamasının altındadır (Şekil 3.2.5).

\subsection{Sosyal bilimler, gazetecilik ve enformasyon dar alanları}

Sosyal bilimler, gazetecilik ve enformasyon geniş alanında iki dar alan ve disiplinler arası programların bulunduğu bir karma alan bulunmaktadır. Sosyal bilimler, gazetecilik ve enformasyon geniş alanındaki programların \%89'u sosyal bilimler ve davranış bilimleri dar alanında sınıflandırılırken, \%9'u gazetecilik ve enformasyon dar alanında sınıflandırılmıştır. Bu geniş alandaki disiplinler arası programlarda sınıflandırılan programların oranı ise \%2'ye yakındır (Şekil 3.3.1).

Öğrencilerin dar alanlar itibariyle dağılımı, program sayısındaki dağılımla paralellik göstermektedir. Buna göre, öğrencilerin \%91,3’ü sosyal bilimler ve davranış bilimleri programlarında, \%8,2'si gazetecilik ve enformasyon programlarında ve \%0,5'i de disiplinler arası programlarda kayıtlıdır (Şekil 3.3.2).

Sosyal bilimler, gazetecilik ve enformasyon geniş alanında program başına düşen öğrenci sayısı ortalama 90'dır. Dar alanlar itibariyle bir farklılaşma gözlenmektedir. Program başına düşen öğrenci sayısı ortalama olarak sosyal bilimler ve davranış bilimleri dar alanında 92, gazetecilik ve enformasyon dar alanında 80 ve disiplinler arası programlarda 27 civarındadır (Şekil 3.3.3).

Öğretim elemanlarının dar alanlar itibariyle dağılımı, öğrenci sayısındaki dağılımla paralellik göstermektedir. Buna göre, öğretim elemanlarının \%92'si sosyal bilimler ve davranış bilimleri programlarında ve \%8'i gazetecilik ve enformasyon programlarında kadroludur (Şekil 3.3.4). 
Sosyal bilimler, gazetecilik ve enformasyon geniş alanında öğretim elemanı başına düșen öğrenci sayısı 35 civarındadır. Dar alanlar itibariyle bir farklılaşma gözlenmemektedir. Öğretim elemanı başına düșen öğrenci sayısı ortalama olarak sosyal bilimler ve davranış bilimleri dar alanında 35, gazetecilik ve enformasyon dar alanında 36'dır. Disiplinler arası programlar, ortak yürütüldüğü için, bu programlara ait kadrolu öğretim elemanı bulunmamaktadır. Sosyal bilimler, gazetecilik ve enformasyon geniş alanındaki dar alanlarda, öğretim elemanı başına düşen öğrenci sayısı, yükseköğrenimdeki 22 olan genel ortalamadan \%59 daha yüksektir (Şekil 3.3.5).

\section{4 İșletme, yönetim ve hukuk dar alanları}

İşletme, yönetim ve hukuk geniş alanında iki dar alan ve disiplinler arası programların bulunduğu bir karma alan vardır. İşletme, yönetim ve hukuk geniş alanındaki programların \%85,2'si işletme ve yönetim dar alanında sinıflandırılırken, \%10,4'ü hukuk dar alanında sınıflandırılmıştır. Bu geniş alandaki disiplinler arası programlarda sınıflandırılan programların oranı ise \%4,4'tür (Şekil 3.4.1).

Öğrencilerin dar alanlar itibariyle dağılımı, program sayısındaki dağılımla paralellik göstermektedir. Buna göre, öğrencilerin \%79'u işletme ve yönetim programlarında, $\% 16$ 'sı hukuk programlarında ve \%5'i de disiplinler arası programlarda kayıtlıdır (Şekil 3.4.2).

İşletme, yönetim ve hukuk geniş alanında program başına düşen öğrenci sayısı ortalama 87'dir. Dar alanlar itibariyle bir farklılaşma gözlenmektedir. Program başına düşen öğrenci sayısı ortalama olarak hukuk dar alanında 132, işletme ve yönetim dar alanında 81 ve disiplinler arası programlarda 95 civarındadır (Şekil 3.4.3).

Öğretim elemanlarının dar alanlar itibariyle dağılımı, öğrenci sayısındaki dağılımla paralellik göstermektedir. Buna göre, öğrencilerin \%74'ü işletme ve yönetim programlarında, \%20,6'sı hukuk programlarında ve $\% 5,3$ 'ü de disiplinler arası programlarda kadroludur (Șekil 3.4.4).

İşletme, yönetim ve hukuk geniş alanında öğretim elemanı başına düşen öğrenci sayısı 47 civarındadır. Dar alanlar itibariyle bir farklılaşma gözlenmektedir. Öğretim elemanı başına düşen öğrenci sayısı ortalama olarak işletme ve yönetim dar alanında 50, hukuk dar alanında 36 ve disiplinler arası programlarda 43'tür. İşletme, yönetim ve hukuk geniş alanında, öğretim elemanı başına düşen öğrenci sayısı, yükseköğrenimdeki 22 olan genel ortalamadan \%114 daha yüksektir (Şekil 3.4.5).

\subsection{Doğa bilimleri, matematik ve istatistik dar alanları}

Doğa bilimleri, matematik ve istatistik geniş alanında dört dar alan ve bir de disiplinler arası programların bulunduğu karma alan bulunmaktadır. Doğa bilimleri, matematik ve istatistik geniş alanındaki programların \%45,5'i biyoloji ve ilişkili bilimler dar alanında, \%32,9'u fen bilimleri dar alanında, \%19,3'ü matematik ve istatistik dar alanında ve $\% 1,1$ 'i çevre dar alanında sınıflandırılmıştır. Bu geniş alandaki disiplinler arası programlarda sinıflandırılan programların oranı ise \%1,1'dir (Şekil 3.5.1).

Öğrencilerin dar alanlar itibariyle dağılımı, program sayısındaki dağılımla paralellik göstermemektedir. Buna göre, öğrencilerin \%43’ü fen bilimleri programlarında, \%29'u biyoloji ve ilişkili bilimler programlarında, \%27'si matematik ve istatistik programlarında, \%0,6'sı çevre programlarında ve \%0,4'ü de disiplinler arası programlarda kayıtlıdır (Şekil 3.5.2).

Doğa bilimleri, matematik ve istatistik geniş alanında program başına düşen öğrenci sayısı ortalama 41 civarındadır. Dar alanlar itibariyle bir farklılaşma gözlenmektedir. Program başına düșen öğrenci sayısı ortalama olarak matematik ve istatistik dar alanında 59 , fen bilimleri dar alanında 54, biyoloji ve ilişkili bilimler dar alanında 26 , çevre programlarında 21 ve disiplinler arası programlarda 15 civarındadır (Şekil 3.5.3).

Öğretim elemanlarının dar alanlar itibariyle dağılımı, öğrenci sayısındaki dağılımla paralellik göstermemektedir. Buna göre, öğretim elemanlarının \%50'si disiplinler arası programlarda, \%25,6'sı matematik ve istatistik programlarında, \%24,6'sı fen bilimleri programlarında ve \%0,1'i çevre programlarında kadroludur (Şekil 3.5.4).

Doğa bilimleri, matematik ve istatistik geniş alanında öğretim elemanı başına düşen öğrenci sayısı 16'dır. Dar alanlar itibariyle bir farklılaşma gözlenmektedir. Öğretim elemanı başına düşen öğrenci sayısı ortalama olarak biyoloji ve ilişkili bilimler dar alanında 19, çevre dar alanında 84 , fen bilimleri dar alanında 14, matematik ve istatistik dar alanında 17 civarındadır. Disiplinler arası programlarda, eğitim diğer dar alanlardaki programlarda kadrolu öğretim elemanları tarafından yürütüldüğü için kadrolu öğretim elemanı bulunmamaktadır. Doğa bilimleri, matematik ve istatistik geniş alanında, öğretim elemanı başına düşen öğrenci sayısı, yükseköğrenimdeki 22 olan genel ortalamadan \%33 daha düşüktür (Şekil 3.5.5).

\subsection{Bilgi ve İletişim Teknolojileri dar alanları}

Bilgi ve iletişim teknolojileri geniş alanındaki programların 1 tanesi disiplinler arası program iken, geriye kalanların tamamı bilgi ve iletişim teknolojileri dar alanında sinıflandırılan programlardır.

Bilgi ve iletişim teknolojileri geniş alanında program sayısının program çeşidine oranı ortalama 6,9 iken, program sayısı başına düşen öğrenci sayısı ortalama 71,2'dir.

Bilgi ve iletişim teknolojileri geniş alanında öğretim elemanı başına düşen öğrenci sayısı 50 civarındadır. Programların tamamı bilgi ve iletişim teknolojileri dar alanındadır. Disiplinler arası program sayısı 1 adet olup, buradaki eğitim de diğer programlarda kadrolu öğretim elemanları tarafından yürütülmektedir. Bilgi ve iletişim teknolojileri geniş alanında, öğretim elemanı başına dü- 
şen öğrenci sayısı, yükseköğrenimdeki 22 olan genel ortalamadan \%127 daha yüksektir (Tablo 5.2).

\subsection{Mühendislik, imalat ve inşaat dar alanları}

Mühendislik, imalat ve inşaat geniş alanında üç dar alan ve bir de disiplinler arası programların bulunduğu karma alan vardır. Mühendislik, imalat ve inşaat geniş alanındaki programların \%56'sı mühendislik ve mühendislik işleri dar alanında, \%25'i mimarlık ve inşaat dar alanında, \%11'i imalat ve işleme dar alanında ve 8 civarındaki kısmı disiplinler arası programlarda sınıflandırılmıştır (Şekil 3.7.1).

Öğrencilerin dar alanlar itibariyle dağılımı, program sayısındaki dağılımla paralellik göstermektedir. Buna göre, öğrencilerin \%59'u mühendislik ve mühendislik işleri programlarında, \%28'i mimarlık ve inşaat programlarında, \%7'si imalat ve işleme programlarında ve \%7'si de disiplinler arası programlarda kayıtlıdır (Şekil 3.7.2).

Mühendislik, imalat ve inşaat geniş alanında program başına düşen öğrenci sayısı ortalama 89,5'tir. Dar alanlar itibariyle bir farklılaşma gözlenmektedir. Program başına düşen öğrenci sayısı ortalama olarak mimarlık ve inşaat dar alanında 97, mühendislik ve mühendislik işleri dar alanında 94, imalat ve işleme dar alanında 59 ve disiplinler arası programlarda 73 civarındadır (Şekil 3.7.3).

Öğretim elemanlarının dar alanlar itibariyle dağılımı, öğrenci sayısındaki dağılımla paralellik göstermemektedir. Buna göre, öğretim elemanlarının \%56'sı mühendislik ve mühendislik işleri programlarında, \%27'si disiplinler arası programlarda, \%9'u mimarlık ve inşaat programlarında, \%8'i imalat ve işleme programlarında kadroludur (Şekil 3.7.4).

Mühendislik, imalat ve inşaat geniş alanında öğretim elemanı başına düşen öğrenci sayısı 29 civarındadır. Dar alanlar itibariyle öğretim elemanı başına düşen öğrenci sayısında çarpıcı farklılıklar gözlenmemektedir. Öğretim elemanı başına düşen öğrenci sayısı mühendislik ve mühendislik işleri dar alanında 31, imalata ve işleme dar alanında 23, mimarlık ve inşaat dar alanında 29 ve disiplinler arası programlarda 25 civarındadır. Mühendislik, imalat ve inşaat geniş alanında, öğretim elemanı başına düşen öğrenci sayısı, yükseköğrenimdeki 22 olan genel ortalamadan \%32 daha yüksektir (Şekil 3.7.5).

\subsection{Ziraat, ormancılık, balıkçılık ve veterinerlik dar alanları}

Ziraat, ormancılık, balıkçılık ve veterinerlik geniş alanında dört dar alan ve bir de disiplinler arası programların bulunduğu karma alan vardır. Ziraat, ormancılık, balıkçllık ve veterinerlik geniş alanındaki programların \%60' 1 ziraat dar alanında, \%18'i veterinerlik dar alanında, \%11'i ormancılık dar alanında, \%8'i balıkçılık dar alanında ve 2 civarındaki kısmı disiplinler arası programlarda sınıflandırılmıştır (Şekil 3.8.1).

Öğrencilerin dar alanlar itibariyle dağılımı, program sayısındaki dağılımla paralellik göstermektedir. Buna göre, öğrencilerin \%54’ü ziraat programlarında, \%27'si veterinerlik programlarında, \%14’ü ormancılık programlarında, \%3,5'i balıkçılık programlarında ve \%2'si de disiplinler arası programlarda kayıtlıdır (Şekil 3.8.2).

Ziraat, ormancılık, balıkçılık ve veterinerlik geniş alanında program başına düşen öğrenci sayısı ortalama 53'tür. Dar alanlar itibariyle bir farklılaşma gözlenmektedir. Program başına düşen öğrenci sayısı ortalama olarak veterinerlik dar alanında 78, ormancilık dar alanında 66, ziraat dar alanında 47, balıkçılık dar alanında 22 ve disiplinler arası programlarda 55 civarındadır (Şekil 3.8.3).

Öğretim elemanlarının dar alanlar itibariyle dağılımı, öğrenci sayısındaki dağılımla paralellik göstermemektedir. Buna göre, öğretim elemanlarının \%40'ı ziraat programlarında, \%37'si balıkçılık programlarında, \%11'i veterinerlik programlarında, \%10'u ormancılık programlarında ve \%2'si de disiplinler arası programlarda kadroludur (Şekil 3.8.4).

Ziraat, ormancılık, balıkçılık ve veterinerlik geniş alanında öğretim elemanı başına düşen öğrenci sayısı 15 civarındadır. Dar alanlar itibariyle öğretim elemanı başına düşen öğrenci sayısında farklılıklar gözlenmektedir. Öğretim elemanı başına düşen öğrenci sayısı ziraat dar alanında 20, ormancılık dar alanında 19, balıkçılık dar alanında 5, veterinerlik dar alanında 11 ve disiplinler arası programlarda 13 civarındadır. Ziraat, ormancılık, balıkçılık ve veterinerlik geniş alanında, öğretim elemanı başına düşen öğrenci sayısı, yükseköğrenimdeki 22 olan genel ortalamadan \%32 daha düşüktür (Şekil 3.8.5).

\subsection{Sağlık ve refah dar alanları}

Sağlık ve refah geniş alanında iki dar alan ve bir de disiplinler arası programların bulunduğu karma alan vardır. Sağlık ve refah geniş alanındaki programların $\% 89,5$ ’ sağlık dar alanında, \%9'u refah dar alanında ve yüzde 2 civarındaki kısmı disiplinler arası programlarda sınıflandırılmıştır (Şekil 3.9.1).

Öğrencilerin dar alanlar itibariyle dağılımı, program sayısındaki dağılımla paralellik göstermektedir. Buna göre, öğrencilerin \%91,4’ü sağlı programlarında, \%8,3’ü refah programlarında ve \%0,3’ü de disiplinler arası programlarda kayıtlıdır (Şekil 3.9.2).

Sağlık ve refah geniş alanında program başına düşen öğrenci sayısı ortalama 63,4'tür. Dar alanlar itibariyle bir farklılaşma gözlenmektedir. Program başına düşen öğrenci sayısı ortalama olarak sağlık dar alanında 65 , refah dar alanında 60 ve disiplinler arası programlarda 12 civarındadır (Şekil 3.9.3).

Öğretim elemanlarının dar alanlar itibariyle dağılımı, öğrenci sayısındaki dağılımla paralellik göstermekle birlikte, sağlığın payı çok daha yüksektir. Buna göre, öğretim elemanlarının \%98,6'sı sağlık programlarında, \%1,4'ü ise refah programlarında kadroludur (Şekil 3.9.4).

Sağlık ve refah geniş alanında öğretim elemanı başına dü- 
şen öğrenci sayısı 7 civarındadır. Dar alanlar itibariyle öğretim elemanı başına düşen öğrenci sayısında çarpıcı bir farklılık gözlenmektedir. Öğretim elemanı başına düşen ögrenci sayısı sağlık dar alanında 7 ve refah dar alanında 42'dir. Disiplinler arası programlar, diğer programlarda kadrolu öğretim elemanları tarafından yürütülmektedir. Sağlık ve refah geniş alanında, öğretim elemanı başına düşen öğrenci sayısı, yükseköğrenimdeki 22 olan genel ortalamadan \%77 daha düşüktür (Şekil 3.9.5).

\subsection{Hizmetler dar alanları}

Hizmetler geniş alanında üç dar alan ve bir de disiplinler arası programların bulunduğu karma alan vardır. Hizmetler geniş alanındaki programların \%52'si kişisel hizmetler dar alanında, \%31'i güvenlik hizmetleri dar alanında ve \%17'si hijyen ve iş sağlığı hizmetleri dar alanında sınıflandırılmıştır (Şekil 3.10.1).

Öğrencilerin dar alanlar itibariyle dağılımı, program sayısındaki dağılımla paralellik göstermektedir. Buna göre, öğrencilerin \%60'i kişisel hizmetler programlarında, \%23'ü güvenlik hizmetleri programlarında ve \%17'si de hijyen ve iş sağlığı programlarında kayıtlıdır. Ulaşım hizmetlerinde kayıtlı ögrencinin görünmüyor olması, kodlamada ulaşımla ilgili programların başka daha çok ilişkili kodlarla tanımlanmasından kaynaklanmaktadır (Şekil 3.10.2).

Hizmetler geniş alanında program başına düşen öğrenci sayısı ortalama 58'dir. Dar alanlar itibariyle bir farklılaşma gözlenmektedir. Program başına düşen öğrenci sayısı ortalama olarak kişisel hizmetler dar alanında 66, hijyen ve iş sağlığ 1 hizmetleri dar alanında 61 ve güvenlik hizmetleri programlarında 43 civarındadır (Şekil 3.10.3).

Öğretim elemanlarının dar alanlar itibariyle dağılımı, öğrenci sayısındaki dağılımdan kısmen farklılaşmaktadır. Buna göre, öğrencilerin \%64'ü kişisel hizmetler programlarında, \%12'si güvenlik hizmetleri programlarında ve \%9'u hijyen ve iş sağlı̆ğ programlarında ve \%15'i de ula- şım hizmetleri programlarında kadroludur (Şekil 3.10.4).

Hizmetler geniş alanında öğretim elemanı başına düşen öğrenci sayısı 45 civarındadır. Dar alanlar itibariyle öğretim elemanı başına düşen öğrenci sayısında farklılıklar gözlenmektedir. Öğretim elemanı başına düşen öğrenci sayısı kişisel hizmetler dar alanında 42, hijyen ve iş sağlığı hizmetleri dar alanında 66 ve güvenlik hizmetleri dar alanında 112'dir. Hizmetler geniş alanında, öğretim elemanı başına düşen öğrenci sayısı, yükseköğrenimdeki 22 olan genel ortalamadan \%105 daha yüksektir (Şekil 3.10.5).

\subsection{Disiplinler arası programlar}

Türk yükseköğrenim sisteminde disiplinler arası programların sayısı oldukça düşüktür. Sağlık, veterinerlik, mühendislik ve öğretmenlik gibi alanların ağırlıklı olarak düzenlenmiş olması, bu alanlarda çeşitlenmeyi sınırlandırmaktadır. Disiplinler arası programların sınırlı olmasının ikinci bir nedeni kamu kurumlarının belirli program veya fakülte adlarını esas alarak personel almalarıdır. Kamu kurumlarının mevzuatlarının değiștirilmesi de pek hızlı olamamaktadır. Kamu kurumlarının bu muhafazakâr tutumu nedeniyle, YÖK'ün denklik prosedürü de paralel bir politika izlemeyi tercih edebilmektedir. Örneğin, matematik-istatistik, istatistik-bilgisayar, biyokimya, yönetim bilişim sistemleri gibi hibrit (disiplinler arası) programlar ekonomik sektörlerin fazlaca ihtiyaç duyduğu bileşik eğitim programları olmalarına rağmen, uygulamada geleneksel programlardan hangilerine eşdeğer (denk) sayılacakları konusundaki belirsizlik nedeniyle, fazlaca rağbet görmemektedir.

Türk yükseköğrenim sisteminde, disiplinler arası programlar toplam program çeşidinde $\% 5,3$, program sayısında \%3,3, öğrenci sayısında \%2,9 ve öğretim elemanı sayısında \%2 oranlarındadır. Program çeşidi bakımından, disiplinler arası programların alanlar itibariyle dağılımında ilk sıralarda mühendislik, imalat ve inşaat (\%42), sağlık ve refah (\%15), işletme, yönetim ve hukuk (\%15)

Tablo 3.1. ISCED dar alanları itibariyle disiplinler arası programların dağılımı (\%)

\begin{tabular}{|c|c|c|c|c|}
\hline Dar alan & $\begin{array}{l}\text { Prog- } \\
\text { ram } \\
\text { çeşidi }\end{array}$ & $\begin{array}{l}\text { Program } \\
\text { sayısı }\end{array}$ & Öğrenci sayısı & $\begin{array}{c}\text { Öğretim } \\
\text { elemanı } \\
\text { sayısı }\end{array}$ \\
\hline 018 Eğitimi kapsayan disiplinler arası programlar ve yeterlilikler & 1,0 & 0,3 & 0,0 & \\
\hline 028 Beşerî bilimler ve sanatı kapsayan disiplinler arası programlar ve yeterlilikler & 13,6 & 14,2 & 8,5 & 7,1 \\
\hline $\begin{array}{l}038 \text { Sosyal ve davranış bilimleri ile gazetecilik ve enformasyonu kapsayan disiplinler arası programlar ve } \\
\text { yeterlilikler }\end{array}$ & 7,8 & 3,7 & 1,5 & \\
\hline 048 İşletme ve hukuku kapsayan disiplinler arası programlar ve yeterlilikler & 14,6 & 24,6 & 36,1 & 26,0 \\
\hline 058 Biyoloji, çevre, fen, matematik ve istatistiği kapsayan disiplinler arası programlar ve yeterlilikler & 3,4 & 2,5 & 0,6 & \\
\hline 068 Bilgi ve iletişim teknolojilerini kapsayan disiplinler arası programlar ve yeterlilikler & 0,3 & 0,1 & & \\
\hline 078 Mühendislik, imalat, mimarlık ve inşaatı kapsayan disiplinler arası programlar ve yeterlilikler & 41,8 & 44,7 & 50,2 & 62,9 \\
\hline 088 Ziraat, ormancılık, balıkçılık ve veterinerliği kapsayan disiplinler arası programlar ve yeterlilikler & 1,7 & 2,0 & 1,7 & 4,0 \\
\hline 098 Sağlık ve refahı kapsayan disiplinler arası programlar ve yeterlilikler & 15,0 & 7,8 & 1,4 & 0,0 \\
\hline 999 Başka yerde sınıflandırılmamış & 0,7 & 0,1 & 0 & 0 \\
\hline Toplam (\%) & 100,0 & 100,0 & 100,0 & 100,0 \\
\hline Toplam disiplinler arası program sayısı & 294 & 1.502 & 97.370 & 3.146 \\
\hline Toplam program sayısı & 5.540 & 45.145 & 3.401 .989 & 156.280 \\
\hline Disiplinler arası program oranı (\%) & 5,3 & 3,3 & 2,9 & 2,0 \\
\hline
\end{tabular}

Kaynak: YÖKSiS veri tabanı 
gelmektedir. Program sayısı bakımından, en fazla disiplinler arası programı bulunan alanlar mühendislik, imalat ve inşaat (\%45), işletme, yönetim ve hukuk (\%25) ve beșeri bilimler ve sanattır (\%14). Disiplinler arası programlarda öğrenim gören öğrencilerin alanlar itibariyle dağılımında ilk sıralarda mühendislik, imalat ve inşaat (\%50), işletme, yönetim ve hukuk (\%36) ve beșerî bilimler ve sanat (\%9) gelmektedir. Disiplinler arası programlarda kadrosu bulunan öğretim elemanlarının \%63’ü mühendislik, imalat ve inşaat, \%26'sı işletme, yönetim ve hukuk ve \%7'si beșerî bilimler ve sanat alanındadır. Disiplinler arası programlarda kadrolu öğretim elemanı sayısı nispeten düşük olup, eğitim önemli ölçüde diğer programlarda kadrolular tarafından yürütülmektedir (Tablo 3.1).

\section{SONUÇ}

\subsection{ISCED geniş alan sınıflamasına göre Türk yükseköğrenim sistemi}

Unesco'nun geliștirdiği uluslararası standart eğitim sınıflamasında (ISCED) birinci seviyede 10 geniş alan, ikinci seviyede 29 dar alan ve üçüncü seviyede 80 civarında ayrıntılı alan bulunmaktadır. Ayrıca disiplinler arası programlar altında birden fazla alanı ilgilendiren programlar, ilgili geniş, dar ve ayrıntılı alan içinde yer almaktadır. 10 geniş alan içinde sınıflandırılamayacak kadar genel içerikte olan programlar "genel programlar ve yeterlilikler" geniş alanı içinde, belirli bir disiplinle ilişkili olmasına rağmen geniş alanların herhangi birinde sınıflandırılmamış olan programlar ise "Başka yerde sınıflandırılmamış" geniş alanı içinde kategorize edilmektedir. Bu haliyle ISCED geniş alan sayısı 12'ye çıkmaktadır. Ancak Türk yükseköğrenim sisteminde bu ilave iki kategori geniş alan olarak yer almamakta, bütün programlar 10 geniş alan içinde sınıflandırılmaktadır. 10 geniş alanın her biri kendi içinde "disiplinler arası", "genel" ve "bilinmeyen veya başka yerde sınıflandırılmamış" kategorilerine sahiptir. Böylece geniş alan sayısı uygulamada10 olarak karşılık bulurken, dar alan sayısı "genel", "disiplinler arası" ve "bilinmeyen" kategorilerini de kapsayarak artmaktadır.

Sonuçta, ISCED sınıflamasında her bir eğitim programına sadece bir kod verilmekte, eğer program, genel, disiplinler arası veya ilgili geniş alandaki dar alanların hiçbirine uymayan bilinmeyen bir program ise, aynı şekilde genel (00 kodu) disiplinler arası (88 kodu) veya bilinmeyen (99 kodu) olarak tek kod verilmektedir. ISCED siniflamasının cevap vermediği ve Türkiye'nin ulusal düzeyde ihtiyaç duyduğu bir konu, ikinci, üçüncü ve hatta dördüncü alanla ilişkilendirmedir. Örneğin, Veterinerlikte Biyoloji ve Genetik tezli yüksek lisans programına, biyoloji, tıbbi genetik ve veterinerlik kodları birlikte verilememektedir. $\mathrm{Bu}$ sorunu aşmanın yolu, ulusal düzeydeki kullanımda, birden fazla kod vermedir. İlk kod ISCED'de öngörüldüğü kurallara göre verilir ve doğrudan kod olarak kabul edilirken, öncelik sırasına göre diğer iki kod dolaylı kod olarak verilir. Türk yükseköğreniminde dolaylı kod kullanımının, yeterlilikler, öğrenme kazanımları ve kalite güvencesi alanındaki karar alıcılar bakımından yararlı olacağı söylenebilir (Toprak ve diğ., 2019).

Türk yükseköğrenim programları, ISCED sinıflaması doğrultusunda 10 geniş alanda sınıflandırıldığında, program çeşidi, program sayısı ve öğrenci sayısı bakımından farklı eğitim düzeylerinin sahip olduğu paylar itibariyle sistemin ana özellikleri ortaya çıkmaktadır. Buna göre, çeşit olarak en fazla program sırasıyla, sanat ve beşerî bilimler (\%18), mühendislik, imalat ve inşaat (\%17), işletme yönetim ve hukuk (\%16), sağlık ve refah (\%13) ve doğa bilimleri, matematik ve istatistik (\%10) geniş alanlarında bulunmaktadır (Şekil 2.1).

Program sayısı bakımından ise en fazla program sırasıyla işletme, yönetim ve hukuk (\%18); mühendislik, imalat ve inşaat (\%17); sağlık ve refah (\%15) ve sanat ve beşerî bilimler (\%14) geniş alanlarındadır.

Öğrenci sayısının geniş alanlar itibariyle dağılımı da benzer bir eğilim taşımaktadır. Öğrenci sayısının en fazla olduğu geniş alanlar sırasıyla işletme, yönetim ve hukuk (\%21); mühendislik, imalat ve inşaat (\%21); sanat ve beșerî bilimler (\%15) ve sağlık ve refahtır (\%13) (Șekil 2.2).

Öğrenci sayısı bakımından en fazla öğrenci sırasıyla işletme, yönetim ve hukuk $(\% 21,3)$, mühendislik, imalat ve inşaat $(\% 20,6)$, sanat ve beşerî bilimler $(\% 14,8)$, sağlık ve refah $(\% 12,6)$ ve eğitim $(\% 9,2)$ geniș alanlarındadır (Șekil 2.5).

Öğrenci sayısının öğrenim düzeyi itibariyle geniş alanlar arasında dağılımında; ön lisansta öğrenim gören öğrencilerin en fazla bulunduğu geniş alanlar işletme, yönetim ve hukuk $(\% 32,5)$, mühendislik, imalat ve inşaat $(\% 19,6)$, sağllk ve refah $(\% 18,6)$, hizmetler $(\% 10,9)$ ve sanat ve beşerî bilimler $(\% 6,1)$ olarak sıralanmaktadır. Lisans düzeyindeki öğrencilerin geniş alanlar arasındaki dağılımında, mühendislik, imalat ve inşaat $(\% 21,5)$, sanat ve beșerî bilimler (\%18,3), işletme, yönetim ve hukuk $(\% 15,9)$, sağllk ve refah $(\% 11,7)$, eğitim $(\% 11,5)$ ve sosyal bilimler, gazetecilik ve enformasyon $(\% 11,4)$ sirasıyla en yüksek paylara sahiptir. Yüksek lisans düzeyinde öğrenim gören öğrencilerin geniş alanlara dağılımında sırasıyla işletme, yönetim ve hukuk $(\% 26,6)$, mühendislik, imalat ve inşaat $(\% 18,3)$, sanat ve beşerî bilimler $(\% 14,5)$, sosyal bilimler, gazetecilik ve enformasyon $(\% 11)$ ve eğitim $(\% 8,6)$ en yüksek paylara sahiptir. Sanatta yeterlik programlarına kayıtlı öğrencilerin \%99,1'i sanat ve beşerî bilimler geniş alanındayken, \%0,9'u mühendislik, imalat ve inşaat geniş alanındadır. Doktora programlarına kayıtlı öğrencilerin geniş alanlar arasındaki dağllımında en yüksek paylar sırasıyla mühendislik, imalat ve inşaat $(\% 21,5)$, işletme, yönetim ve hukuk $(\% 16,4)$, sanat ve beșerî bilimler (\%15,8), doğa bilimleri, matematik ve istatistik $(\% 13,6)$ ve sosyal bilimler, gazetecilik ve enformasyondur (\%10,4) (Tablo 2.1).

Geniş alan bazında, farklı öğrenim düzeylerine kayıtlı öğrencilerin oranları, ilgili geniş alandaki programların he- 
defledikleri işgücü piyasası hakkında önemli bir ipucu verir. Örneğin, bilgi ve iletişim teknolojileri geniş alanında kayıtlı ögrencilerin \%80'i ön lisans, \%14,4'ü lisans, \%4,8'i yüksek lisans ve $\% 0,7$ 'si doktora programlarında öğrenim görmektedir. Buna göre, bilgi ve iletişim geniş alanının hedef işgücü piyasasının ağırlıklı olarak ara teknik eleman olduğu, akademik amaçlı eğitimden ziyade mesleki yönelimli eğitimin amaçlandığı söylenebilir (Tablo 2.2).

Geniş alan bazında, toplam öğrenci sayısı içinde ön lisansta kayıtlı öğrenci sayısının en yüksek olduğu beş geniş alan sırasıyla bilgi ve iletişim teknolojileri (\%80), hizmetler (\%60), işletme, yönetim ve hukuk (\%39), sağlık ve refah (\%37) ve ziraat, ormancılık, balıkçılık ve veterinerliktir (\%29). Dolayısıyla, bu geniş alanların işgücü piyasasının ara eleman ihtiyacını karşılamaya göreli olarak daha fazla yoğunlaştığı söylenebilir. Lisans düzeyindeki öğrenci oranının en yüksek olduğu beş geniş alan sırasıyla sosyal bilimler, gazetecilik ve enformasyon (\%81), eğitim (\%76), sanat ve beşerî bilimler (\%75), doğa bilimleri, matematik ve istatistik (\%69) ve mühendislik, imalat ve inşaattır (\%63). Toplam öğrenci sayısı içinde en yüksek oranda yüksek lisans öğrencisine sahip olan ilk beş geniş alan sırasıyla doğa bilimleri, matematik ve istatistik (\%21), ziraat, ormancılık, balıkçılık ve veterinerlik (\%16), sosyal bilimler, gazetecilik ve enformasyon (\%15), işletme, yönetim ve hukuk (\%14) ve sanat ve beşerî bilimlerdir (\%11). Toplam öğrencileri içinde doktoraya kayıtlı öğrenci oranı en yüksek olan ilk beş geniş alan ise sırasıyla doğa bilimleri, matematik ve istatistik $(\% 8,4)$, ziraat, ormancıllk, balıkçllk ve veterinerlik $(\% 4,4)$, sosyal bilimler, gazetecilik ve enformasyon $(\% 3,3)$, sanat ve beşeri bilimler $(\% 2,9)$ ve mühendislik, imalat ve inşaattır $(\% 2,8)$ (Tablo 2.2).

Doktora eğitimi, bir ülkedeki ar-ge altyapısını oluşturmada kritik önemdedir. Bu nedenle, doktoraya kayıtlı öğrenci kapasitesi, Türk ekonomisinin inovasyon yöneliminin hangi geniş alanlarda potansiyele sahip olduğunu göstermesi bakımından önemlidir.

Öğretim elemanlarının geniş alanlar arasında dağılımında ise ilk beş geniş alan arasında çarpıcı farklar söz konusudur. Buna göre öğretim elemanlarının en fazla olduğu geniş alanlar sırasıyla sağlık ve refah (\%38), mühendislik, imalat ve inşaat (\%15), sanat ve beşeri bilimler (\%14) ve işletme, yönetim ve hukuktur (\%10) (Şekil 2.6).

Toplam program sayısının öğrenim düzeyleri itibariyle dağılımında, geniş alanlar birbirinden önemli düzeyde farklılaşmaktadır. Buna göre bilgi ve iletişim teknolojileri alanındaki programların \%67'si ön lisans düzeyinde iken, bu oran hizmetlerde $\% 64$, sağlık ve refahta $\% 47$, işletme, yönetim ve hukukta \%41 ve ziraat, ormancılık, balıkçılık ve veterinerlikte \%33'tür. Lisans program sayısının toplam program sayısı içinde oransal olarak en yüksek olduğu beş geniş alan sırasıyla sosyal bilimler, gazetecilik ve enformasyon (\%44), sanat ve beşerî bilimler (\%39), eğitim (\%34), mühendislik, imalat ve inşaat (\%33) ve işletme, yönetim ve hukuktur (\%21). Yüksek lisans program sayısı- nın oransal olarak en yüksek olduğu beș geniş alan sırasiyla doğa bilimleri, matematik ve istatistik (\%48), eğitim (\%42), sosyal bilimler, gazetecilik ve enformasyon (\%41), işletme, yönetim ve hukuk (\%32) ve sanat ve beşeri bilimlerdir (\%30). Doktora program sayısının oransal olarak en yüksek olduğu beş geniş alan sırasıyla doğa bilimleri, matematik ve istatistik (\%32), ziraat, ormancılık, balıkçılık ve veterinerlik (\%21), sağlık ve refah (\%15), sosyal bilimler, gazetecilik ve enformasyon (\%13) ve mühendislik, imalat ve inşaattır (\%13) (Tablo 5.4).

Sonuç olarak, Türkiye gibi yaygın ve kitlesel eğitimi hedefleyen bir ülke için, eğitim sisteminin dayanacağı ekonomik sektörler, nüfusunun sahip olması hedeflenen beceri envanteri ve nihayet ulusal ve bölgesel olarak kendisini konuşlandırmayı hedeflediği ekosistemi bir bütün olarak değerlendiren ve bu doğrultuda sistemik ve sistematik bir yükseköğrenim ve araştırma ajandası geliştiren yaklaşıma ihtiyaç vardır. El yordamıyla ve piyasanın reaktif olarak gecikmelerle de olsa geliştirdiği çözümler, önemli ölçüde zaman kaybına ve rekabetçi ekonomi ve toplum iddiasının giderek daha zor ulaşılabilir olmasına neden olacaktır.

\subsection{ISCED dar alan sınıflamasına göre Türk yükseköğrenim sistemi}

ISCED dar alan sayısı, geniş alan bazında değişmektedir. Dolayısıyla her bir dar alan kapsamındaki ayrıntılı alan sayısı da farklılaşmaktadır. Buna göre sadece 1 dar alanı bulunan geniş alanlar eğitim ile bilgi ve iletişim teknolojileri; 2 dar alanı bulunan geniş alanlar sosyal bilimler, gazetecilik ve enformasyon, işletme, yönetim ve hukuk ile sağlık ve refah; 3 dar alanı bulunan geniş alanlar, genel programlar ve yeterlilikler, sanat ve beşerî bilimler ile mühendislik, imalat ve inşaat; 4 dar alanı bulunan geniş alanlar ise doğa bilimleri, matematik ve istatistik, ziraat, ormancılık, balıkçılık ve veterinerlik ile hizmetlerdir. Genel programlar ve yeterlilikler geniş alanı içinde kodlanan herhangi bir program olmadığı için fiilen geniş alan sayısı 10'dur.

Eğitim geniş alanında, sadece 1 dar alan (eğitim) bulunmaktadır. Hem program sayısı başına düşen öğrenci sayısı ve hem de öğretim elemanı başına düşen öğrenci sayısı, Türkiye ortalamalarının üzerindedir.

Sanat ve beşerî bilimler geniş alanında 3 dar alan 1 de disiplinler arası programların bulunduğu karma alan vardır. En fazla program sırasıyla sanat, beşerî bilimler ve diller dar alanlarında bulunurken; en fazla öğrenci sırasıyla beşeri bilimler, sanat ve diller dar alanındaki programlarda kayıtlıdır. Program başına düşen öğrenci sayısı, Türkiye ortalamasının biraz üzerinde olup, sanat ve beşerî bilimler geniş alanı altındaki dar alanlar itibariyle farklılaşma göstermektedir. Buna göre, program sayısı başına düşen öğrenci sayısının yüksekten düşüğe doğru sanat, diller, beşerî bilimler ve disiplinler arası programlar olarak sıralanmaktadır. Öğretim elemanlarının dar alanlar itibariyle dağılımı, öğrencilerin dağılımına paralellik göstermekte- 
dir. Buna göre, öğretim elemanlarının en fazla bulunduğu dar alanlar beșerî bilimler, sanat ve diller olarak sıralanmaktadır. Sanat ve beșerî bilimler geniş alanında öğretim elemanı bașına düșen öğrenci sayısı, Türkiye ortalamasının biraz üzerindedir. Öğretim elemanı başına düşen öğrenci sayısı dar alanlar arasında farklılaşmaktadır. En yüksek ortalama sırasıyla disiplinler arası programlar, diller, beşeri bilimler ve sanat dar alanlarına aittir.

Sosyal bilimler, gazetecilik ve enformasyon geniş alanında 2 dar alan 1 de disiplinler arası programların bulunduğu karma alan vardır. Programların ağırlıklı kısmı sosyal bilimler ve davranış bilimlerine aitken, gazetecilik ve enformasyon \%9 oranında paya sahiptir. Yaklaşı olarak aynı oranlar, öğrencilerin dar alanlar itibariyle dağılımında da geçerlidir. Program başına düşen öğrenci sayısı, her iki dar alan bakımından farklı olup ve her iki oran da Türkiye ortalamasının üzerindedir. Program sayısı başına düşen öğrenci sayısı sosyal bilimler ve davranış bilimlerinde, gazetecilik ve enformasyon dar alanına göre daha yüksektir. Öğretim elemanlarının dar alanlar itibariyle dağılımı, öğrencilerin dağılımına paralellik göstermektedir. Öğretim elemanı başına düşen öğrenci sayısı, Türkiye ortalamasının üzerindedir. Öğretim elemanı başına düşen öğrenci sayısı her ki dar alan için yaklaşık aynı düzeydedir.

İşletme, yönetim ve hukuk geniş alanında 2 dar alan 1 de disiplinler arası programların bulunduğu karma alan vardır. Programların ağırlıklı kısmı işletme ve yönetim dar alanına aitken, hukuk dar alanı $\% 10$ oranında paya sahiptir. Bu oranlar yaklaşı olarak, öğrencilerin dar alanlar itibariyle dağılımında da geçerlidir. Program başına düşen öğrenci sayısı, her iki dar alan bakımından farklı olup ve her iki oran da Türkiye ortalamasının üzerindedir. Program sayısı başına düşen öğrenci sayısı hukukta, işletme ve yönetim dar alanına göre daha yüksektir. Öğretim elemanlarının dar alanlar itibariyle dağılımı, öğrencilerin dağılımına paralellik göstermektedir. Öğretim elemanı başına düşen öğrenci sayısı, Türkiye ortalamasının üzerindedir. Öğretim elemanı başına düşen öğrenci sayısı işletme ve yönetim dar alanında, hukuk dar alanına göre daha yüksektir.

Doğa bilimleri, matematik ve istatistik geniş alanında 4 dar alan 1 de disiplinler arası programların bulunduğu karma alan vardır. Programların yarıya yakını biyoloji ve ilişkili bilimler dar alanına aitken, üçte biri fen bilimlerine ve beşte biri de matematik ve istatistik dar alanına aittir. Öğrencilerin dar alanlar itibariyle dağılımında ise en yüksek paya fen bilimleri, biyoloji ve ilişkili bilimler ile matematik ve istatistik programları sahiptir. Program başına düşen öğrenci sayısı, Türkiye ortalamasının hayli altında olup, dar alanlar bakımından farklılaşmaktadır. Program sayısı başına düşen öğrenci sayısı sırasıyla en çok matematik ve istatistik, fen bilimleri, biyoloji ve ilişkili bilimler ve çevre dar alanlarındadır. Öğretim elemanlarının dar alanlar itibariyle dağılımı, öğrencilerin dağılımına paralellik göstermemektedir. Öğretim elemanlarının yarısı di- siplinler arası programlarda iken, dörtte birlik kısımları matematik ve istatistik ile fen bilimleri programlarındadır. Öğretim elemanı başına düşen öğrenci sayısı, Türkiye ortalamasının altındadır. Temel doğa bilimleri programlarına yönelik düşük talep, hoca başına düşen öğrenci göstergesini olumlu yönde etkilemiştir.

Bilgi ve iletişim teknolojileri geniş alanında 1 dar alan, 1 de disiplinler arası programların bulunduğu karma alan vardır. Programların tamamına yakını bilgi ve iletişim teknolojileri dar alanına aittir. Öğrencilerin tamamı bu dar alandaki programlara kayıtlıdır. Program başına düşen öğrenci sayısı, Türkiye ortalamasının biraz altındadır. Öğretim elemanı başına düşen öğrenci sayısı, Türkiye ortalamasının hayli üstündedir.

Mühendislik, imalat ve inşaat geniş alanında 3 dar alan 1 de disiplinler arası programların bulunduğu karma alan vardır. Programların yarıdan fazlası mühendislik ve mühendislik işleri dar alanına aitken, dörtte biri mimarlık ve inşaata, yüzde 11 'i imalat ve inşaata ve geriye kalanı da disiplinler arası programlara aittir. Öğrencilerin dar alanlar itibariyle dağılımı, program sayısındaki dağılıma paralellik göstermektedir. Program başına düşen öğrenci sayısı, Türkiye ortalamasının üzerinde olup, dar alanlar bakımından farklılaşmaktadır. Program sayısı başına düşen öğrenci sayısı mimarlık ve inşaat ile mühendislik ve mühendislik işleri dar alanlarında Türkiye ortalamasının üzerinde iken; imalat ve işleme ile disiplinler arası programlarda altındadır. Öğretim elemanlarının yarısından fazlası mühendislik ve mühendislik işleri programlarında kadroluyken, dörtte birinden biraz fazlası disiplinler arası programlarda, yüzde 9'u mimarlık ve inşaatta ve yüzde 8'i de imalat ve işleme programlarındadır. Öğretim elemanı başına düşen öğrenci sayısı, Türkiye ortalamasının biraz üzerinde olup, dar alanlar itibariyle çarpıcı bir farklılaşma göstermemektedir.

Ziraat, ormancilık, balıkçılık ve veterinerlik geniş alanında 4 dar alan 1 de disiplinler arası programların bulunduğu karma alan vardır. Programların yarıdan fazlası ziraat dar alanına aitken, bește birine yakını veterinerliğe, yüzde 11'i ormancıllğa ve yüzde 8'i de balıkçılığa aittir. Öğrencilerin dar alanlar itibariyle dağılımı, program sayısındaki dağılıma paralellik göstermektedir. Program başına düşen öğrenci sayısı, Türkiye ortalamasının altında olup, dar alanlar bakımından farklılaşmaktadır. Sadece veterinerlik programlarına kayıtlı öğrenci ortalaması Türkiye ortalamasının üzerinde, olup diğerlerinde daha düşüktür. Öğretim elemanlarının beşte dördüne yakını yaklaşık oranlarda ziraat ve balıkçılık programlarında kadroludur. Yine veterinerlik ve ormancılık programlarında kayıtlı öğretim elemanlarının oranları da yüzde 10'ar civarındadır. Bütün dar alanlarda öğretim elemanı başına düșen öğrenci sayıs1, Türkiye ortalamasının altında olup, dar alanlar itibariyle çarpıcı bir farklılaşma göstermemektedir.

Sağlık ve refah geniş alanında 2 dar alan 1 de disiplinler arası programların bulunduğu karma alan vardır. Prog- 
ramların ağılıklı kısmı sağlık dar alanına aitken, onda birine yakını refah dar alanına aittir. Öğrencilerin dar alanlar itibariyle dağılımı, program sayısındaki dağılıma paralellik göstermektedir. Program başına düşen öğrenci sayısı, Türkiye ortalamasının altında olup, dar alanlar bakımından çarpıcı bir farklılaşma göstermemektedir. Öğretim elemanlarının yaklaşık yüzde 98,6'sı sağlık programlarında, yüzde 1,4'ü de refah programlarında kadroludur. Sağlık dar alanında öğretim elemanı başına düşen öğrenci sayısı 6,7 iken, refah programlarında bu oran 42,4'tür. Sağlık ve refah birlikte dikkate alındığında $(7,3)$, oranın Türkiye ortalamasına göre (22) oldukça düşük olduğu söylenebilir.

Hizmetler geniş alanında 4 dar alan 1 de disiplinler arası programların bulunduğu karma alan vardır. Ancak ulaştırma dar alanında kayıtlı öğrenci bulunmadığı için, analizler 3 dar alan bağlamında yapılacaktır. Programların yarıdan fazlası kişisel hizmetler dar alanına aitken, üçte birine yakını güvenlik hizmetleri dar alanına aittir. Hijyen ve iş sağlı̆̆ hizmetleri dar alanındaki programların oranı ise yüzde 17'ye yakındır. Öğrencilerin dar alanlar itibariyle dağılımı, program sayısındaki dağılıma paralellik göstermektedir. Program başına düșen öğrenci sayısı, Türkiye ortalamasının altında olup, dar alanlar bakımından farklılaşmaktadır. Öğretim elemanlarının yaklaşık üçte ikisine yakını kişisel hizmetler, yüzde 15'e yakını ulaşım hizmetleri, yüzde 12'si güvenlik hizmetleri ve yüzde 9 civarındaki kısmı ise hijyen ve iş sağlığı hizmetleri programlarında kadroludur. Hizmetler geniş alanında öğretim elemanı başına düşen öğrenci sayısı 45 olup, Türkiye ortalamasının üstündedir. Dar alanlar itibariyle öğretim elemanı başına düşen öğrenci sayısı çarpıcı şekilde farklılaşmaktadır.

Bilgi ve iletişim teknolojileri, iş yapma usulleri, artan entegrasyon ve küreselleşme, yükseköğrenim programlarının disiplinler arası olmasını, araştırma ve eğitimin uluslararasılaşmasını ve düzenlenmiş ve yapılandırılmış programların daha esnek olmasını beraberinde getirmektedir. Ne var ki Türk yükseköğrenim sistemi hayli katı olup, söz konusu bağlamlarda esnekliğe ve yeniliğe oldukça soğuk bakmaktadır. Kamu kesiminin istihdamındaki tanımlı ve esnek olmayan kurallar, ulusal mevzuatın da katı ve tanımlı olmaya devam etmesini desteklemektedir.

\subsection{Politika önerileri}

Türk yükseköğrenim sistemi, derece yapısı, yeterlilikler çerçevesi, kalite güvencesi, tematik üniversite, bölgesel kalkınma odaklı misyon üniversitesi ve yükseköğrenime kitlesel erişim konularında, her birinde aynı düzeyde olmasa da yasal ve kurumsal asgari gerekleri yerine getirmiş durumdadır. Organizasyonel yapının işlevsel olarak etkinleștirilmesi ve işbirliği ve eşgüdüm boşluklarının en aza indirilmesi için işlevsel mimarinin geliştirilmesi gerekmektedir. Dolayısıyla, yönetim ve işletim modelinin yasal ve kurumsal altyapısı ile birlikte tasarımına ihtiyaç vardır. 29-30 Mart 2017 tarihinde Brüksel'de Türki- ye eğitim sistemi (ana sınıfından doktoraya kadar bütün eğitim düzeyleri) Avrupa Birliği eğitim sistemiyle bütün yönleriyle referanslanmış ve onaylanmıştır. Ne var ki, eğitime ilişkin standartlar, yeterlilikler, kalite güvencesi, akreditasyon, transfer ve tanınma konuları statik olmayıp sürekli bir devinim içindedir. Bu nedenle, yönetişim modelinin söz konusu dinamizmi sürekli kılacak șekilde tasarımı gereklidir.

Türk yükseköğrenim sisteminde halihazırda üç farklı yeterlilikler çerçevesi fiilen uygulamada görünüyor. Birincisi, resmi ve ulusal olan, Bakanlar Kurulunca onaylanan, Avrupa Komisyonuna sunulan ve uygun görülen ve ana sınıfından doktoraya bütün eğitim düzeylerini kapsayan Türkiye Yeterlilikler Çerçevesidir (2015). Halihazırdaki mevzuatımıza göre tek resmi çerçeve budur. Fiilen uygulanıyor görünen ikinci çerçeve Türkiye Yükseköğretim Yeterlilikler Çerçevesidir (2009). Bu ikinci çerçeve birincisi hazırlanmadan önce YÖK bünyesinde hazırlandı ve Avrupa Yükseköğrenim Alanı Yeterlilikler Çerçevesi (EHEA-QF) ile Avrupa Yeterlilikler Çerçevesi (AYÇ) harmanlanarak en beğenilen ifade ve önermeleri alınarak oluşturuldu. Üçüncü çerçeve ise yine YÖK bünyesinde hazırlandı ve YÖK ve ÜAK'ın ilan ettiği temel alanlar baz alınarak temel alan yeterlilikleri olarak ilan edildi (2011). Sonuç olarak, Bakanlar Kurulu tarafından onaylanan, Avrupa Komisyonuna sunularak onaylanan, bütün eğitim düzeylerini kapsayan tek resmi çerçeve 2015 tarihli olandır. Ancak, halen YÖK'ün ilgili sayfalarında 2009 ve 2013 tarihli çerçeveler görünmekte, esas resmi olan çerçeveye ise bir atıf dahi bulunmamaktadır. Bu durum, TYÇ'nin Türk yükseköğrenim sistemini standartlar, kalite güvencesi, akreditasyon, tanınma ve denklik ile önceki öğrenmelerin tanınması konularındaki dönüștürücü ve iyileştirici işlevlerini görmesinin önünde kurumsal bir engel oluşturmaktadır.

YÖK bünyesinde geliştirilen temel alan yeterlilikleri çalışması, Avrupa yükseköğrenim alanı reform gündeminde öngörülen sektörel yeterliliklere karşılık gelmektedir. Dolayısıyla, sektörel yeterlilik kavramının negatif çağrışımlarını bertaraf etmek için, alan yeterlilikleri tabiri tercih edilmiştir. Ne yazık ki, sektör yerine alan sözcüğü tercih edilince, bu sefer bağlamda kopukluk oldu ve sektörün ihtiyaçları ve öncelikleri bir tarafa bırakılarak, niyetlenenin tam tersi bir durum ortaya çıktı ve bilimsel alan yeterlilikleri gibi bir doküman oluşturuldu. Bu kavramsal kargaşayı izale etmek için, YÖK nezdindeki çalışmalarda aktif olarak yer alan araştırmacılardan bazıları tarafından "alan yeterlilikleri" üzerine alternatif bir çerçeve geliştirme çalışması yapılarak yayınlandı (Toprak, Erdoğan ve Açıkgöz, 2013). Çalışma, sektörel yeterlilikleri belirleme amacı taşıyan temel alan yeterlilikleri dokümanının kavramsal yanlışlığına ve eğer bilimsel alanlara yönelik bir çerçeve geliştirilecekse, bunun nasıl olması gerektiğine ilişkin bir çalışmadır.

Alan yeterlilikleri çerçevesinin oluşturulmasında, UNES- 
CO’nun geliștirdiği ve belirli aralıklarla güncellediği ve bu çalışmada Türk yükseköğrenim sistemine uygulanarak analiz edilen ISCED sınıflaması vardır. ISCED'in bilimsel alan yaklaşımı, YÖK-ÜAK'ın yaklaşımına paralellik göstermekle birlikte önemli farklılıklar da göstermektedir. Dolayısıyla hem uluslararası karşılaștırma ve raporlamalarda hem de ulusal ihtiyaçların karşılanmasında MEB, MYK, ISS-KUR, TÜIK gibi kurumlarla işbirliği yapılmasında ISCED sınıflamasının esas alınması kaçınılmazdır.

Bu çalışmada Türk yükseköğrenim sistemi, ISCED geniş ve dar alanları bazında program çeşidi ve program sayısı ile öğrenci ve öğretim elemanları sayıları bakımından analiz edilerek, geniş ve dar bilimsel alanlar itibariyle sistemin genel özellikleri ortaya konmuştur. ISCED sınıflamasında ayrıntılı alan çalışmasının da yapılması gerekmektedir ki, bu çalışmanın devamını oluşturacaktır. Ulusal düzeyde ISCED'in daha işlevsel olması için, üçüncü çalışmanın program bazında yapılmasıdır.

ISCED ayrintılı alan ve program bazında betimsel analizler yapıldıktan sonra, alan standartları ve yeterlilikleri, sektörel standartlar ve yeterlilikler, kalite güvencesi, akreditasyon, önceki öğrenmelerin tanınması ve transferi konularındaki yasal ve kurumsal düzenlemeler, bütüncül ve tutarlı bir sistem dahilinde gündeme gelebilecektir. Bu s1ralama veya bütünlük gözetilmeden yapılacak çalışmalar, bugünkü dağınıklığın gösterdiği gibi, birbirinden kopuk ve enerji tüketici olacak, belki yararından daha fazla her türlü reforma kuşku ve kaygıyla bakılmasına yol açacaktır.

Sayısal ve coğrafi olarak büyük bir yayılım gösteren Türk yükseköğrenim sisteminin en azından sayısal analizini en genelden (geniş bilimsel alan) en özele (program içindeki anabilim dalı altındaki bilim dalı) yapmadan, genel geçer ezberlerle politika geliştirme uzun soluklu olumlu sonuçlar doğurmamaktadır.

\section{REFERANSLAR}

ILO. (1988). International Standard Classification of Occupations, ISCO-88. https://www.lo.org/public/english/bureau/ stat/isco/isco08/

ILO. (2008). International Standard Classification of Occupations, ISCO-08. https://www.lo.org/public/english/bureau/ stat/isco/isco08/index.htm

Mongkolhutthi, Preechaya. (2019). Inequality and imbalance of professional development opportunities: The case of a higher educational institution in Southeast Asia. Journal of Applied Research in Higher Education. https://doi. org/10.1108/JARHE-01-2018-0010

MYK. (2016). Turkish Referencing Report, http://tyc.gov.tr/trr. pdf

Nguyen, Thi Van Su ve Laws, Kevin. (2019). Changes in higher education teachers' perceptions of curriculum. Journal of Applied Research in Higher Education, 11(1), 76-89.

Schneider, Silke L. (2013). The International Standard Classification of Education 2011, içinde, Elisabeth Birkelund, G. (Ed.) Class and Stratification Analysis, Comparative Social Research. 30, 365-379.
Stonkiene, Marija, Matkeviciene, Renata ve Vaiginiene, Erika. (2016). Evaluation of the national higher education system's competitiveness: Theoretical model. Competitiveness Review. 26(2), 116-131.

Tay, Huay Ling ve Low, Stephen Wee Kiat. (2017), Digitalization of learning resources in a $\mathrm{HEI}-\mathrm{a}$ lean management perspective. International Journal of Productivity and Performance Management, 66(5), 680-694.

Toprak, Metin, Kolat, Deniz ve Şengül, Mehmet. (2018). ISCED Eğitim ve Öğretim Alanları 2013 (ISCED-F 2013) Kılavuzu. Yükseköğretim Dergisi, 8(1), 113-123.

Toprak, Metin ve Erdoğan, Armağan. (2013). Lisansüstü eğitimde Avrupa yaklaşımı. VI. Ulusal Lisansüstü Eğitim Sempozyumu, Bildiriler Kitabı, Sakarya Üniv. Y., 95, 10-36.

Toprak, Metin, Erdoğan, Armağan ve Açıkgöz, Ömer. (2013). Field qualifications: A framework suggestion. The New Educational Review. 31(1), 153-164.

Toprak, Metin, Kolat, Deniz, Şengül, Mehmet ve Erdoğan, Armağan. (2019). Türk Yükseköğreniminin Görünümü: Betimsel Bir Analiz. Üniversite Araştırmaları Dergisi, Ağustos, 2(3), basımda.

UNESCO. (2015). International Standard Classification of Education: Fields of Education and Training 2013 (ISCED-F 2013) - Detailed Field Descriptions. http://uis.unesco.org/ sites/default/files/documents/international-standard-classification-of-education-fields-of-education-and-training-2013-detailed-field-descriptions-2015-en.pdf

UNSD. (2008). International Standard Industrial Classification of all Economic Activities (ISIC). https://unstats.un.org/ unsd/iiss/International-Standard-Industrial-Classification-of-all-Economic-Activities-ISIC.ashX

YÖK. (2009). Türkiye Yükseköğretim Yeterlilikler Çerçevesi, http://tyyc.yok.gov.tr

YÖK. (2011). Temel Alan Yeterlilikleri. http://tyyc.yok.gov.tr/?pid $=48$

Wu, Yen-Chun Jim ve Shen, Ju-Peng. (2016). Higher education for sustainable development: a systematic review. International Journal of Sustainability in Higher Education. 17(5), 633-651.

Yağan Saadet Aylin, \& Çubukçu Zühal. (2019). Türkiye ve İngiltere doktora programlarının karşılaştııılması. Yükseköğretim ve Bilim Dergisi. 9(1), 134-143. 


\section{EKLER}

Tablo 5.1. ISCED geniş alanları itibariyle, program çeşidi ve sayısı ile öğrenci ve öğretim elemanı sayıları

\begin{tabular}{|c|c|c|c|c|c|c|c|}
\hline Geniş alan & $\begin{array}{l}\text { Program } \\
\text { çeşidi }\end{array}$ & $\begin{array}{l}\text { Program } \\
\text { sayısı }\end{array}$ & $\begin{array}{l}\text { Öğrenci } \\
\text { sayısı }\end{array}$ & $\begin{array}{l}\text { Öğretim elema- } \\
\text { nı sayısı }\end{array}$ & $\begin{array}{l}\text { Program çeşidi } \\
\text { başına program } \\
\text { sayısı }\end{array}$ & $\begin{array}{l}\text { Program sayısı } \\
\text { başına öğrenci } \\
\text { sayısı }\end{array}$ & $\begin{array}{c}\text { Öğretim elemanı } \\
\text { başına öğrenci } \\
\text { sayısı }\end{array}$ \\
\hline 01 Eğitim & 395 & 3.941 & 311.349 & 8.943 & 10,0 & 79,0 & 34,8 \\
\hline 02 Sanat ve beşeri bilimler & 979 & 6.411 & 502.012 & 21.274 & 6,5 & 78,3 & 23,6 \\
\hline $\begin{array}{l}03 \text { Sosyal bilimler, gazetecilik ve } \\
\text { enformasyon }\end{array}$ & 474 & 3.222 & 290.123 & 8.193 & 6,8 & 90,0 & 35,4 \\
\hline 04 Işletme, yönetim ve hukuk & 903 & 8.320 & 724.917 & 15.397 & 9,2 & 87,1 & 47,1 \\
\hline $\begin{array}{l}05 \text { Doğa bilimleri, matematik ve } \\
\text { istatistik }\end{array}$ & 545 & 3.586 & 148.134 & 9.274 & 6,6 & 41,3 & 16,0 \\
\hline 06 Bilgi ve İletişim Teknolojileri & 107 & 738 & 52.540 & 1.047 & 6,9 & 71,2 & 50,2 \\
\hline 07 Mühendislik, imalat ve inşaat & 926 & 7.850 & 702.374 & 24.004 & 8,5 & 89,5 & 29,3 \\
\hline $\begin{array}{l}08 \text { Ziraat, ormancilık, balıkçılık ve } \\
\text { veterinerlik }\end{array}$ & 256 & 1.646 & 87.068 & 5.753 & 6,4 & 52,9 & 15,1 \\
\hline 09 Sağlık ve refah & 703 & 6.744 & 427.778 & 58.924 & 9,6 & 63,4 & 7,3 \\
\hline 10 Hizmetler & 250 & 2.685 & 155.694 & 3.471 & 10,7 & 58,0 & 44,9 \\
\hline 99 Başka yerde sınıflandırılmamış & 2 & 2 & - & 0 & 1,0 & & \\
\hline Toplam / Ortalama & 5.540 & 45.145 & 3.401.989 & 156.280 & 8,1 & 75,4 & 21,8 \\
\hline
\end{tabular}

Kaynak: YÖKSIS veri tabanı, Mart 2019

Tablo 5.2. ISCED dar alanları itibariyle, program, öğrenci ve öğretim elemanı sayıları

\begin{tabular}{|c|c|c|c|c|c|c|}
\hline $\begin{array}{l}\frac{\frac{c}{\pi}}{\pi} \\
\frac{1}{\pi} \\
0\end{array}$ & 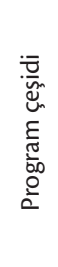 & 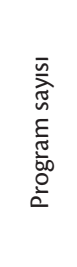 & 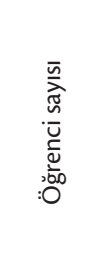 & 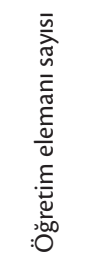 & 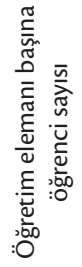 & 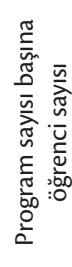 \\
\hline 011 Eğitim & 392 & 3.937 & 311.316 & 8.943 & 34,8 & 79,1 \\
\hline 018 Eğitimi kapsayan disiplinler arası programlar ve yeterlilikler & 3 & 4 & 33 & - & & 8,3 \\
\hline 021 Sanat & 495 & 3.110 & 158.453 & 9.472 & 16,7 & 50,9 \\
\hline 022 Beşeri bilimler (diller hariç) & 203 & 1.670 & 200.659 & 7.762 & 25,9 & 120,2 \\
\hline 023 Diller & 241 & 1.417 & 134.615 & 3.816 & 35,3 & 95,0 \\
\hline 028 Beşeri bilimler ve sanatı kapsayan disiplinler arası programlar ve yeterlilikler & 40 & 214 & 8.285 & 224 & 37,0 & 38,7 \\
\hline 031 Sosyal bilimler ve davranış bilimleri & 392 & 2.870 & 264.928 & 7.539 & 35,1 & 92,3 \\
\hline 032 Gazetecilik ve enformasyon & 59 & 297 & 23.732 & 654 & 36,3 & 79,9 \\
\hline $\begin{array}{l}038 \text { Sosyal ve davranış bilimleri ile gazetecilik ve enformasyonu kapsayan disiplinler } \\
\text { arası programlar ve yeterlilikler }\end{array}$ & 23 & 55 & 1.463 & - & & 26,6 \\
\hline 041 İşletme ve yönetim & 764 & 7.085 & 575.771 & 11.404 & 50,5 & 81,3 \\
\hline 042 Hukuk & 96 & 866 & 114.011 & 3.176 & 35,9 & 131,7 \\
\hline 048 İşletme ve hukuku kapsayan disiplinler arası programlar ve yeterlilikler & 43 & 369 & 35.135 & 817 & 43,0 & 95,2 \\
\hline 051 Biyoloji ve ilişkili bilimler & 238 & 1.633 & 42.383 & 2.280 & 18,6 & 26,0 \\
\hline 052 Çevre & 16 & 41 & 843 & 10 & 84,3 & 20,6 \\
\hline 053 Fen bilimleri & 190 & 1.181 & 63.784 & 4.611 & 13,8 & 54,0 \\
\hline 054 Matematik ve istatistik & 91 & 693 & 40.569 & 2.373 & 17,1 & 58,5 \\
\hline $\begin{array}{c}058 \text { Biyoloji, çevre, fen, matematik ve istatistiği kapsayan disiplinler arası programlar } \\
\text { ve yeterlilikler }\end{array}$ & 10 & 38 & 555 & - & & 14,6 \\
\hline 061 Bilgi ve Illetişim Teknolojileri (ICT) & 106 & 737 & 52.540 & 1.047 & 50,2 & 71,3 \\
\hline 068 Bilgi ve iletişim teknolojilerini kapsayan disiplinler arası programlar ve yeterlilikler & 1 & 1 & - & - & & \\
\hline 071 Mühendislik ve mühendislik işleri & 500 & 4.361 & 411.197 & 13.369 & 30,8 & 94,3 \\
\hline 072 İmalat ve işleme & 117 & 829 & 48.507 & 2.075 & 23,4 & 58,5 \\
\hline 073 Mimarlık ve inşaat & 186 & 1.988 & 193.776 & 6.581 & 29,4 & 97,5 \\
\hline $\begin{array}{l}078 \text { Mühendislik, imalat, mimarlık ve inşaatı kapsayan disiplinler arası programlar ve } \\
\text { yeterlilikler }\end{array}$ & 123 & 672 & 48.894 & 1.979 & 24,7 & 72,8 \\
\hline 081 Ziraat & 144 & 995 & 47.066 & 2.303 & 20,4 & 47,3 \\
\hline 082 Ormancilık & 41 & 180 & 11.813 & 625 & 18,9 & 65,6 \\
\hline 083 Balıkçılık & 36 & 139 & 3.071 & 580 & 5,3 & 22,1 \\
\hline 084 Veterinerlik & 30 & 302 & 23.458 & 2.120 & 11,1 & 77,7 \\
\hline $\begin{array}{c}088 \text { Ziraat, ormancılık, balıkçılık ve veterinerliği kapsayan disiplinler arası programlar } \\
\text { ve yeterlilikler }\end{array}$ & 5 & 30 & 1.660 & 125 & 13,3 & 55,3 \\
\hline 091 Sağlık & 607 & 6.034 & 391.119 & 58.090 & 6,7 & 64,8 \\
\hline
\end{tabular}




\begin{tabular}{|c|c|c|c|c|c|c|}
\hline $\begin{array}{l}\frac{\pi}{\pi} \\
\frac{\pi}{\pi} \\
\frac{\pi}{0}\end{array}$ & 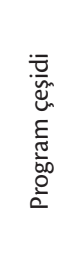 & 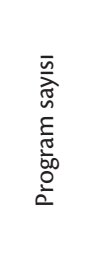 & 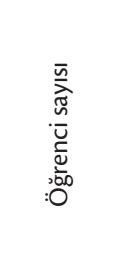 & 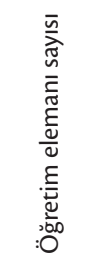 & 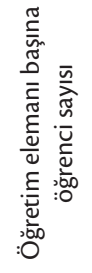 & 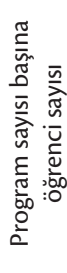 \\
\hline 092 Refah & 52 & 593 & 35.314 & 833 & 42,4 & 59,6 \\
\hline 098 Sağlık ve refahı kapsayan disiplinler arası programlar ve yeterlilikler & 44 & 117 & 1.345 & 1 & 1345,0 & 11,5 \\
\hline 101 Kişisel hizmetler & 131 & 1.400 & 92.931 & 2.233 & 41,6 & 66,4 \\
\hline 102 Hijyen ve iş sağlığı hizmetleri & 26 & 444 & 26.841 & 408 & 65,8 & 60,5 \\
\hline 103 Güvenlik hizmetleri & 44 & 301 & 13.743 & 321 & 42,8 & 45,7 \\
\hline 104 Ulaşım hizmetleri & 49 & 540 & 22.179 & 509 & 44,9 & 41,1 \\
\hline 999 Başka yerde sınıflandırılmamış & 2 & 2 & - & - & & \\
\hline Toplam / Ortalama & 5.540 & 45.145 & 3.401 .989 & 156.280 & 21,8 & 75,4 \\
\hline Toplam (Disiplinler arası) & 294 & 1.502 & 97.370 & 3.146 & 31,0 & 64,8 \\
\hline Disiplinler arası oranı (\%) & 5,3 & 3,3 & 2,9 & 2,0 & & \\
\hline
\end{tabular}

Kaynak: YÖKSIS veri tabanı

Tablo 5.3. Öğrenim düzeyi bazında, program çeşidi, sayısı ve öğrencilerinin geniş alanlar arasında dağılımı (\%)

\begin{tabular}{|c|c|c|c|c|c|c|c|c|c|c|c|c|c|c|c|c|c|c|}
\hline \multirow[b]{2}{*}{ 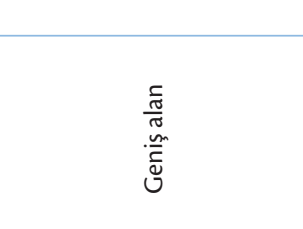 } & \multicolumn{6}{|c|}{ Program çeşidi } & \multicolumn{6}{|c|}{ Program sayısı } & \multicolumn{6}{|c|}{ Öğrenci sayısı } \\
\hline & $\frac{\frac{E}{\pi}}{\frac{0}{0}}$ & 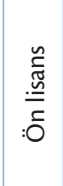 & $\underset{\substack{\mathbb{N}\\
}}{\beth}$ & 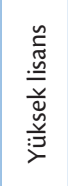 & 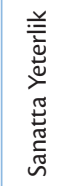 & $\begin{array}{l}\frac{\sigma}{0} \\
\frac{0}{0} \\
0\end{array}$ & $\frac{\frac{E}{\pi}}{\frac{0}{0}}$ & $\begin{array}{l}\stackrel{\mathscr{\simeq}}{\widetilde{N}} \\
\stackrel{\underline{\underline{N}}}{\simeq} \\
: 0\end{array}$ & $\underset{\mathscr{c}}{\stackrel{n}{\leftrightarrows}}$ & 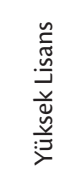 & 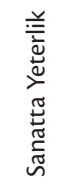 & 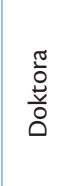 & $\frac{\frac{\varepsilon}{0}}{\frac{0}{0}}$ & $\begin{array}{l}\stackrel{\mathscr{n}}{\widetilde{n}} \\
\stackrel{\underline{n}}{\check{c}} \\
: 0\end{array}$ & 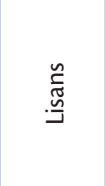 & 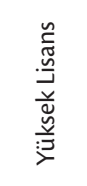 & 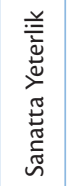 & $\begin{array}{l}\frac{\pi}{0} \\
\frac{0}{0} \\
\frac{8}{0}\end{array}$ \\
\hline 01 Eğitim & 7,1 & 0,8 & 7,0 & 8,4 & 0,0 & 7,7 & 8,7 & 3,4 & 11,0 & 12,0 & 0,0 & 8,5 & 9,2 & 3,9 & 11,5 & 8,6 & 0,0 & 7,1 \\
\hline 02 Sanat ve beşeri bilimler & 17,7 & 10,8 & 36,0 & 13,6 & 98,4 & 15,6 & 14,2 & 8,0 & 20,5 & 14,0 & 99,3 & 13,6 & 14,8 & 6,1 & 18,3 & 14,5 & 99,1 & 15,8 \\
\hline $\begin{array}{l}03 \text { Sosyal bilimler, gazeteci- } \\
\text { lik ve enformasyon }\end{array}$ & 8,6 & 1,8 & 6,7 & 10,8 & 0,0 & 8,0 & 7,1 & 0,5 & 11,7 & 9,6 & 0,0 & 7,1 & 8,5 & 0,3 & 11,4 & 11,0 & 0,0 & 10,4 \\
\hline $\begin{array}{c}04 \text { İşletme, yönetim ve } \\
\text { hukuk }\end{array}$ & 16,3 & 21,3 & 13,4 & 19,7 & 0,0 & 8,4 & 18,4 & 26,0 & 14,2 & 19,1 & 0,0 & 9,2 & 21,3 & 32,5 & 15,9 & 26,6 & 0,0 & 16,4 \\
\hline $\begin{array}{c}05 \text { Doğa bilimleri, matema- } \\
\text { tik ve istatistik }\end{array}$ & 9,8 & 1,5 & 6,5 & 10,0 & 0,0 & 15,9 & 7,9 & 0,4 & 5,2 & 12,6 & 0,0 & 19,7 & 4,4 & 0,2 & 4,9 & 8,1 & 0,0 & 13,6 \\
\hline $\begin{array}{l}06 \text { Bilgi ve İletişim Tekno- } \\
\text { lojileri }\end{array}$ & 1,9 & 2,7 & 1,6 & 2,2 & 0,0 & 1,3 & 1,6 & 3,8 & 0,7 & 1,0 & 0,0 & 0,4 & 1,5 & 4,9 & 0,4 & 0,7 & 0,0 & 0,4 \\
\hline $\begin{array}{l}07 \text { Mühendislik, imalat ve } \\
\text { inşaat }\end{array}$ & 16,7 & 26,3 & 14,7 & 14,9 & 1,6 & 18,2 & 17,4 & 17,0 & 20,8 & 15,0 & 0,7 & 17,0 & 20,6 & 19,6 & 21,5 & 18,3 & 0,9 & 21,5 \\
\hline $\begin{array}{l}08 \text { Ziraat, ormancılık, balık- } \\
\text { çılık ve veterinerlik }\end{array}$ & 4,6 & 10,0 & 4,2 & 3,2 & 0,0 & 5,7 & 3,6 & 4,1 & 2,2 & 3,5 & 0,0 & 6,0 & 2,6 & 3,0 & 2,1 & 3,7 & 0,0 & 4,2 \\
\hline 09 Sağlık ve refah & 12,7 & 12,2 & 4,2 & 13,5 & 0,0 & 16,7 & 14,9 & 23,9 & 9,8 & 10,2 & 0,0 & 17,2 & 12,6 & 18,6 & 11,7 & 4,7 & 0,0 & 9,2 \\
\hline 10 Hizmetler & 4,5 & 12,5 & 5,6 & 3,6 & 0,0 & 2,3 & 5,9 & 13,0 & 4,0 & 3,0 & 0,0 & 1,3 & 4,6 & 10,9 & 2,2 & 3,9 & 0,0 & 1,4 \\
\hline $\begin{array}{c}99 \text { Başka yerde sınıflandı- } \\
\text { rılmamış }\end{array}$ & 0,0 & 0,0 & 0,0 & 0,0 & 0,0 & 0,1 & 0,0 & 0,0 & 0,0 & 0,0 & 0,0 & 0,0 & 0,0 & 0,0 & 0,0 & 0,0 & 0,0 & 0,0 \\
\hline Toplam (sayı) & 5.540 & 600 & 733 & 2.907 & 63 & 1.237 & 45.145 & 13.189 & 12.231 & 13.714 & 138 & 5.873 & 3.401 .989 & 858.350 & 2.062 .674 & 388.232 & 1.223 & 91.51 \\
\hline Toplam (\%) & 100,0 & 100,0 & 100,0 & 100,0 & 100,0 & 100,0 & 100,0 & 100,0 & 100,0 & 100,0 & 100,0 & 100,0 & 100,0 & 100,0 & 100,0 & 100,0 & 100,0 & 100,0 \\
\hline
\end{tabular}

Kaynak: YÖKSIS Veri Tabanı, YÖK İstatistik Veri Tabanı.

Tablo 5.4. Geniş alan bazında, program çeşidi, sayısı ve öğrencilerinin öğrenim düzeyi itibariyle dağılımı (\%)

\begin{tabular}{|c|c|c|c|c|c|c|c|c|c|c|c|c|c|c|c|c|c|c|}
\hline \multirow[b]{2}{*}{$\begin{array}{l}\frac{c}{\pi} \\
\frac{\pi}{\pi} \\
\frac{\omega}{\pi} \\
心\end{array}$} & \multicolumn{6}{|c|}{ Program çeşidi } & \multicolumn{6}{|c|}{ Program sayısı } & \multicolumn{6}{|c|}{ Öğrenci sayısı } \\
\hline & $\frac{\frac{\varepsilon}{\pi}}{\frac{0}{0}}$ & 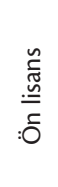 & $\begin{array}{l}\stackrel{n}{\mathbb{N}} \\
\stackrel{\mathscr{N}}{=}\end{array}$ & 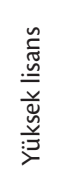 & 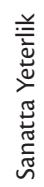 & 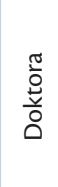 & $\begin{array}{l}\frac{\varepsilon}{\frac{\varepsilon}{0}} \\
\frac{0}{0} \\
\vdash\end{array}$ & $\begin{array}{l}\stackrel{\mathscr{c}}{\mathbb{N}} \\
\stackrel{\underline{E}}{c} \\
: 0\end{array}$ & 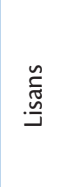 & 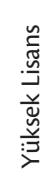 & 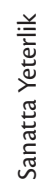 & $\begin{array}{l}\frac{\pi}{0} \\
\frac{\vec{U}}{0} \\
0\end{array}$ & $\frac{\frac{\varepsilon}{\pi}}{\frac{0}{0}}$ & 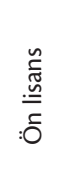 & $\begin{array}{l}\tilde{n} \\
\stackrel{\tilde{N}}{=}\end{array}$ & 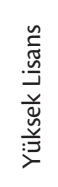 & 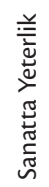 & $\begin{array}{l}\frac{0}{0} \\
\frac{\dot{0}}{0} \\
0\end{array}$ \\
\hline 01 Eğitim & 395 & 1,3 & 12,9 & 61,8 & 0,0 & 24,1 & 3.941 & 11,3 & 34,0 & 41,9 & 0,0 & 12,7 & 311.349 & 10,8 & 76,4 & 10,7 & 0,0 & 2,1 \\
\hline 02 Sanat ve beşeri bilimler & 979 & 6,6 & 27,0 & 40,3 & 6,3 & 19,7 & 6.411 & 16,4 & 39,1 & 30,0 & 2,1 & 12,4 & 502.012 & 10,4 & 75,3 & 11,2 & 0,2 & 2,9 \\
\hline $\begin{array}{c}03 \text { Sosyal bilimler, gazetecilik ve } \\
\text { enformasyon }\end{array}$ & 474 & 2,3 & 10,3 & 66,5 & 0,0 & 20,9 & 3.222 & 1,9 & 44,4 & 40,8 & 0,0 & 12,9 & 290.123 & 0,9 & 81,2 & 14,7 & 0,0 & 3,3 \\
\hline 04 Isşletme, yönetim ve hukuk & 903 & 14,2 & 10,9 & 63,5 & 0,0 & 11,5 & 8.320 & 41,2 & 20,8 & 31,5 & 0,0 & 6,5 & 724.917 & 38,5 & 45,2 & 14,2 & 0,0 & 2,1 \\
\hline $\begin{array}{c}05 \text { Doğa bilimleri, matematik ve } \\
\text { istatistik }\end{array}$ & 545 & 1,7 & 8,8 & 53,4 & 0,0 & 36,1 & 3.586 & 1,5 & 17,9 & 48,3 & 0,0 & 32,3 & 148.134 & 1,4 & 68,9 & 21,3 & 0,0 & 8,4 \\
\hline 06 Bilgi ve Illetişim Teknolojileri & 107 & 15,0 & 11,2 & 58,9 & 0,0 & 15,0 & 738 & 67,2 & 11,1 & 18,6 & 0,0 & 3,1 & 52.540 & 80,0 & 14,4 & 4,8 & 0,0 & 0,7 \\
\hline 07 Mühendislik, imalat ve inşaat & 926 & 17,1 & 11,7 & 46,9 & 0,1 & 24,3 & 7.850 & 28,6 & 32,5 & 26,1 & 0,0 & 12,8 & 702.374 & 24,0 & 63,1 & 10,1 & 0,0 & 2,8 \\
\hline $\begin{array}{l}08 \text { Ziraat, ormancılık, balıkçlık ve } \\
\text { veterinerlik }\end{array}$ & 256 & 23,4 & 12,1 & 36,7 & 0,0 & 27,7 & 1.646 & 33,1 & 16,2 & 29,4 & 0,0 & 21,3 & 87.068 & 29,4 & 49,8 & 16,4 & 0,0 & 4,4 \\
\hline
\end{tabular}




\begin{tabular}{|c|c|c|c|c|c|c|c|c|c|c|c|c|c|c|c|c|c|c|}
\hline & \multicolumn{6}{|c|}{ Program çeşidi } & \multicolumn{6}{|c|}{ Program sayısı } & \multicolumn{6}{|c|}{ Öğrenci sayısı } \\
\hline 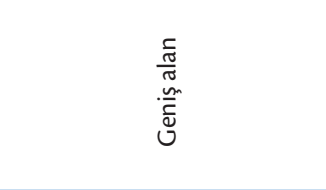 & $\begin{array}{l}\frac{\varepsilon}{\frac{\pi}{0}} \\
\frac{0}{\circ}\end{array}$ & $\begin{array}{l}\stackrel{\mathscr{n}}{\tilde{N}} \\
\stackrel{\underline{\underline{n}}}{\widetilde{L}} \\
: 0\end{array}$ & $\begin{array}{l}\stackrel{\mathscr{c}}{\bar{m}} \\
\stackrel{\mathscr{M}}{ב}\end{array}$ & 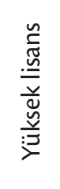 & 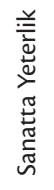 & $\begin{array}{l}\frac{\pi}{0} \\
\frac{\tilde{\theta}}{0} \\
0\end{array}$ & $\begin{array}{l}\frac{E}{\sigma} \\
\frac{0}{\circ}\end{array}$ & 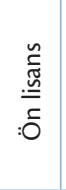 & 䔍 & 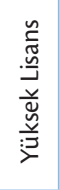 & 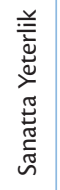 & $\begin{array}{l}\frac{\pi}{0} \\
\frac{0}{0} \\
\frac{0}{0}\end{array}$ & $\frac{\frac{\varepsilon}{\sigma}}{\frac{0}{0}}$ & 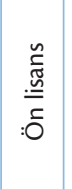 & 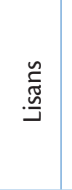 & 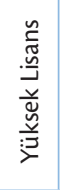 & 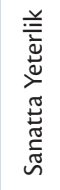 & $\begin{array}{l}\frac{\pi}{0} \\
\frac{0}{0} \\
\frac{0}{0}\end{array}$ \\
\hline 09 Sağlık ve refah & 703 & 10,4 & 4,4 & 55,8 & 0,0 & 29,4 & 6.744 & 46,7 & 17,7 & 20,6 & 0,0 & 14,9 & 427.778 & 37,4 & 56,4 & 4,2 & 0,0 & 2,0 \\
\hline 10 Hizmetler & 250 & 30,0 & 16,4 & 42,0 & 0,0 & 11,6 & 2.685 & 63,8 & 18,2 & 15,1 & 0,0 & 2,8 & 155.694 & 60,1 & 29,3 & 9,8 & 0,0 & 0,8 \\
\hline 99 Başka yerde sınıflandırılmamış & 2 & 0,0 & 0,0 & 50,0 & 0,0 & 50,0 & 2 & 0,0 & 0,0 & 50,0 & 0,0 & 50,0 & & & & & & \\
\hline Toplam (sayı) & 5.540 & 10,8 & 13,2 & 52,5 & 1,1 & 22,3 & 45.145 & 29,2 & 27,1 & 30,4 & 0,3 & 13,0 & 3.401 .989 & 25,2 & 60,6 & 11,4 & 0,04 & 2,7 \\
\hline
\end{tabular}

Kaynak: YÖKSIS Veri Tabanı, YÖK İstatistik Veri Tabanı. 